\title{
GRAND DESIGN OF EDUCATIONAL INSTITUTIONS IN CHARACTER EDUCATION \\ (An analysis of problems and New Formulations, in the approach to character education)
}

\author{
Reksiana ${ }^{1}$ \\ Dosen Fakultas Tarbiyah Institut IImu Al-Qur'an Jakarta' \\ Email : reksiana@iiq.ac.id
}

\begin{abstract}
the existence of differences of view to education children character, and can be classified in several categories and theories. This difference is seen as some figures say families or tualah people are the most important in providing character education. Others argue sekolahlah that is most vital in respect of containers of character education. This article uses a qualitative approach, with the kind of Library Research. Therefore, the overall data focuses on books or papers relating to discussion of "rightmost character Education". Quant à la méthode d'analyse de données technique utilisée est descriptive analyse qualitative méthodes, car les données sont traitées sous la forme d'un écrit de données telles que : livres, revues, articles de journaux, caractère education curriculum directives structures formelles en 2013 en ligne En ligne) et comprend le produit brut standard sous forme de législation relative à la formation du caractère.

From the results of the discussion and anlisa above, concrete conclusions can be taken, that the person in charge character education namely Educational Institutions not the independence of each other, but rather inherently. Summary this rests on a concrete analysis of the various figures such as: Thomas Lickona, Jun Sung Hong and James Garbarino, David w. Johnson, and Roger $t$. Johnson, even from muslim figures like Abdul Majid, Jamal 'Abdur Rahman, Moh. Solikodin Djaelani, Muchlas Samani dan Abdullah Nashih 'Ulwan, first product reinforced by legislation which clearly explains the $R I$ character education is the shared responsibility of educational institutions.
\end{abstract}

Keyword: Educational Institutions, character education, families, schools and communities, and Character Education.

Abstrak Adanya perbedaan pandangan terhadap pendidikan karakter anak, dan dapat diklasifikasikan dalam beberapa kategori dan teori. Perbedaan ini dilihat seperti sebagian tokoh mengatakan keluarga atau orang tualah yang paling utama dalam memberikan pendidikan karakter. Sebagian lain berpendapat sekolahlah yang merupakan wadah paling vital dalm pendidikan karakter. Aritkel ini menggunakan pendekatan kualitatif, dengan jenis penelitian perpustakaan (Library Research). Oleh karena itu, keseluruhan data menitikberatkan pada buku atau karya tulis yang berkaitan dengan pembahasan "Pendidikan Karaker". Adapun metode teknik analisis data yang dipakai adalah metode analisis kualitatif deskriptif, karena data yang diolah berupa data-data tertulis seperti: buku-buku pendidikan karakter, pedoman kurikulum 2013 di lembaga formal, jurnal, artikel, koran daring (online) dan termasuk standar baku berupa produk undang-undang yang berkaitan dengan pendidikan karakter.

Dari hasil bahasan dan anlisa di atas, dapat diambil kesimpulan yang konkret, bahwa penangung jawab pendidikan karakter yaitu Educational Institutions tidak independensi satu sama lain, melainkan inheren. Simpulan ini bersandar pada analisa konkret dari berbagai tokoh seperti: Thomas Lickona, Jun Sung Hong dan James Garbarino, David W. Johnson and Roger T. Johnson, bahkan dari tokoh-tokoh muslim seperti Abdul Majid, Jama>l 'Abdur Rahma>n, Moh. Solikodin Djaelani, Muchlas Samani dan 'Abdullah Nashih 'Ulwan, selanjut diperkuat oleh produk undangundang RI yang secara jelas menerangkan pendidikan karakter merupakan tanggung jawab bersama dari Institusi Pendidikan.

Kata kunci: Institut Pendidikan, Pendidikan Karakter, Keluarga, Sekolah dan Masyarakat, dan Pendidikan Karakter.

\section{PENDAHULUAN}

Dalam dunia pendidikan, pendidikan karakter sudah menjadi bahasan yang lazim, khususnya di Indonsia. Dan bila tilik lebih jauh, terkait dengan pendidikan karakter, terdapat beberapa perbedaan pandangan tentang tangung jawab siapa 
yang menjadi penanggung jawab penuh terhadap pendidikan karakter anak. Terkait hal ini, maka akan adanya perbedaan pendapat atau pandangan yang dapat diklasifikasikan dalam beberapa pandangan dan teori. Ada sebagian pendapat yang mengatakan bahwa keluarga atau orang tualah yang paling utama dalam memberikan pendidikan karakter.

Pendapat lain memandang bahwa sekolah merupakan tempat yang paling strategis dan paling utama dalam memberikan pendidikan karakter. Dan, jika dikaji lebih mendalam, bahwa, terkait dengan adanya anggapan bahwa pendidikan karakter sudah harus diajarkan di sekolah, sebagaimana anggapan dari Thomas Lickona, yang menunjukkan ada sepuluh alasan mengapa pendidikan karakter harus diterapakan di sekolah. Namun tidak sedikit pula yang kontra terhadap pandangan tersebut (Thomas Lickona, 1991).

Kemudian yang sebagian lain, berpendapat jika tanggung jawab pendidikan karakter harus adanya integrasi antara sekolah dan orang tua. Perdebatanperdebatan ini tentang apakah pendidikan karakter harus diajarkan atau tidak di sekolah telah berlangsung lebih dari beberapa dekade. Berkenaan dengan hal ini, bahwa pendidikan karakter di sekolah dapat dilakukan dengan menggunakan berbagai pendekatan, namun lebih menekankan pada peranan program yang ada di sekolah, peran guru dan pimpinan sekolah yang paling dominan dalam memberikan contoh teladan kepada para siswanya.

Penerapan pendidikan karakter di sekolah juga dicanangkan oleh lembaga pusat pengembangan kurikulum ASCD (Association for Supervision and Curriculum Development) yang mengintegrasikan pendidikan karakter ke dalam kurikulum dengan pendekatan holistik. Dalam penerapannya pendekatan holsitik ini pada aspek kegiatan sehari-hari siswa di sekolah (budaya sekolah) dan ke dalam kegiatan ekstrakurikuler (Justin R. E. Rawana and Raymond, 2011).

Demikian juga Justin R.E. Rawana turut memberikan keterangan jika pendidikan karakter lebih ditekankan pada program yang ada di sekolah. Pada tataran ini, Justin menawarkan program yang disandarkan pada program mentoring. Program ini menurutnya dapat mengembangkan karakter positif anak. Pada program mentoring ini dilakukan oleh guru serta pihak sekolah (Justin R. E. Rawana and Raymond, 2011).

Terkait pendidikan karakter ditangerai di sekolah, Mary M. Williams juga mengungkapkan bahwa pendidikan karakter hendaknya dilaksanakan di sekolah. Hal ini dinyatakan dengan menggunakan pendekatan holistik (Mary M. Williams, 2000) dan komprehensif. Selain terintegrasi pada unsur-unsur yang ada di sekolah, juga dengan menggunakan beberapa aspek perkembangan anak yang meliputi kognitif, afektif, dan domain perilaku. Penjelasan lebih lajut, menurutnya, pendekatan parsial yang hanya menitikberatkan pada unsur-unsur kognitif atau afektif saja tidak ada pengaruh bagi mayoritas anak-anak (Mary M. Williams, 2000). Temuan lain dalam hal ini oleh M. S. Omar Fauzee yang dalam studinya menunjukkan jika pada pendidikan karakter bisa disinergikan pada kegiatan atau mata pelajaran olahraga. Indikasi dari hali ini orang yang berpartisipasi dalam olahraga dapat menumbuhkan karakter positif (M. S. Omar Fauzee, 2012). Sementara, Rodney H. Clarken menganggap bahwa hal terpenting dalam pendidikan karakter adalah kecerdasan moral. Pernyataan ini didasari oleh acuan pada kemampuan anak untuk menerapkan prinsip-prinsip etis untuk tujuan pribadi, nilainilai dan tindakan (Rodney H. Clarken, 2009).

Selain sekolah, ada bebarapa penulis yang memandang bahwa orang tua (keluarga) merupakan aspek yang paling berperan dalam pendidikan karkater anak. Karena pengaruh keluarga pada setiap jenjang usia sama besarnya, bukan hanya di 
masa kanak-kanak saja, meskipun pada usia tertentu sebagian anggota keluarga memiliki pengaruh yang lebih dominan dibanding dengan yang lain (Djawad Dahlan dan Juntika Nurihsan, 2014). Dengan kata lain, selain orang tua, saudara juga memiliki pengaruh meski tidak terlalu dominan. Gabriel Madinier yang dikutip oleh K. Bertens mengatakan bahwa tempat yang strategis dalam pendidikan moral anak adalah keluarga, bukan sekolah. Jika pendidikan moral dalam keluarga berjalan dengan baik, sekolah atau pendidikan formal tidak lagi memiliki peran yang signifikan dalam pembentukan karakter anak (K. Bertens, 2007). Dalam hal ini, orang tua mempunyai otoritas untuk menanamkan nilai-nilai moral dan kebaikan.

Di kalangan pemikir muslim seperti al-Nahlawi, Ahmad Tafsir, Muhammad Taqi Falsafi dan Zakiah Daradjat berpendapat bahwa keluarga merupakan wadah pertama yang memiliki peran paling sentral bagi pertumbuhan dan perkembangan seorang anak. Jika lingkungan keluarga baik, anak akan tumbuh dengan baik pula. Sebaliknya, jika lingkungan tidak baik, perkembangan anak juga akan terhambat. Jelasnya, orang tualah yang memiliki pengaruh yang signifikan dalam memberikan pendidikan karakter (Abd al Rahman Al-Nahlawi, 2008). Memberikan ulasan mengapa pendidikan karakter menjadi tanggung jawab orang tua, menurutnya, karakter sangat terkait dengan keimanan individual serta merupakan faktor yang meluruskan tabi'at yang rusak dan memperbaiki jiwa manusia. Tanpa pendidikan iman, maka perbaikan karakter tidak akan tercipta. Keterangan ini dipertegas dengan adanya hadis-hadis pedagogis (Abdullah Nashih Ulwan, 1981) yang menerangkan bahwa jika orang tua adalah penanggung jawab utama terhadap pendidikan dasar anak (Abdullah Nashih Ulwan, 1981).

Sebagai contoh bentuk dari tanggung jawab orang tua yang berhubungan dengan pendidikan moral anak seperti orang tua mendidik anak mereka dari sejak kecil untuk berlaku benar, dapat dipercaya, istiqamah, dan mencintai orang lain. Orang tua juga bertanggung jawab agar anak mereka tidak berkata buruk (mencela). Orangtua bertanggung jawab untuk menumbuhkan kepekaan terhadap anak mereka, seperti berbuat baik kepada anak yatim, fakir dan lain-lain (Abdullah Nashih Ulwan, 1981).

Selain ketiga institusi tersebut di atas, terdapat satu aspek lagi yang memberikan pengaruh besar terhadap karakter atau kepribadian anak, yaitu internet. Kemampuan internet yang dapat mengonvergensi interconnectednetworking (internet) sebagai media baru di era globalisasi tidak hanya menghadirkan kemudahan dan kenyamanan hidup bagi manusia akan tetapi juga permasalahan baru kedalam kehidupan keluarga dan sekolah yang semula dibangun dan sarat nilai-nilai moral/norma. Berbagai ketersediaan fitur serta fungsinya yang perannya dapat menimbulkan pengaruh positif dan negatif dalam kehidupan manusia. Pengaruh dari internet ini tidak bisa dipungkiri dan dielakkan. Karena hal ini menitikberatkan pada perkembangan zaman dan adanya pola perubahan budaya.

Beberapa penulisan yang dapat membuktikan bahwa adanya pengaruh besar internet termasuk salah satunya media sosial terkait karakter siswa. Pembuktian ini dinyatakan oleh Muhammad Riyan Adi Permana lewat metode ex-post facto. Hasil dari studinya yaitu (1) Pengaruh penggunaan internet terhadap karakter siswa adalah positif dan signifikan yang dibuktikan dengan nilai korelasi sebesar 0,161 ; (2) Pengaruh kontrol sosial terhadap karakter siswa adalah positif dan signifikan yang dibuktikan dengan nilai korelasi sebesar 0,299; (3) Kontrol diri memiliki pengaruh positif dan signifikan terhadap karakter siswa yang dibuktikan dengan nilai korelasi sebesar 0,367; Sedangkan (4) Penggunaan internet, kontrol sosial, kontrol diri berpengaruh positif dan signifikan terhadap karakter siswa yang 
dibuktikan dengan koefisien korelasi sebesar 0,500 (Muhammad Riyan Adi Permana, 2019).

Pembuktian lain oleh Meita Purnamasari Augustin ini bertujuan mengkaji pengaruh terpaan media internet terhadap karakter siswa. Augustin menerapkan jenis studi pola "The dominant-less dominant design" dengan pendekatan kuantitatif melalui metode survey. Hasil studinya membuktikan bahwa: Pertama, karakter siswa dipengaruhi terpaan media internet. Terpaan informasi global dari media internet berpengaruh dalam proses mengubah kepribadian, sistem budaya, tata nilai, gaya hidup dan perilaku seseorang. Kedua, intensitas penggunaan media internet berpengaruh terhadap karakter berkenaan dengan konsep diri berupa penilaian tentang diri (self esteem) dan pengendalian diri (self control) agar tidak kecanduan internet yang dapat mengganggu kepribadian dan berdampak pada berkurangnya interaksi antar manusia di kehidupan nyata.

Temuan ketiga, Terpaan media internet dengan motif kesenangan berpengaruh terhadap karakter berkenaan dengan kemampuan self knowledge, self control dan will untuk berbuat baik. Keempat, terpaan media internet melalui motif edukatif berpengaruh terhadap karakter berkenaan dengan self control dengan cara pembiasaan (habit), pembudayaan dan diaplikasikan dalam proses pembelajaran pendidikan kewarganegaraan, kultur sekolah, keluarga, kelompok teman sebaya dan media massa. Kelima, intensitas penggunaan dengan motif kesenangan dan edukatif yang terarah akan menghasilkan aktivitas produktif, kreatif dan berpengaruh terhadap karakter siswa sebagai landasan kognisi baru bagi terbentuknya sikap, watak dan konsep nilai moral dalam diri sehingga menyadari hakikat teknologi diciptakan untuk memudahkan manusia dalam memecahkan masalah kehidupannya (Meita Purnamasari Augustin, 2010).

Bila ditelaah secara komprehensif, perkembangan karakter tidak bisa hanya ditekankan atau tanggung jawab hanya pada lembaga-lembaga tertentu saja seperti keluarga, sekolah atau masyarakat saja, namun perlu dipahami jika karakter yang baik juga bisa terdapat dalam potensi yang baik dalam diri seseorang. Pendidik karakter juga bukan hanya guru dalam kelas saja, namun bisa dilakukan oleh orang tua, diri sendiri, dan kehidupan atau lingkungan (Erie Sudewo, 2011). Untuk itu, dalam pendidikan karakter diperlukan rumusan yang bukan hanya mengkaji content-nya saja, tapi harus juga dengan pendekatan yang lebih komprehensif. Hal ini perlu dilakukan untuk mengingat permaslaahan di dunia pendidikan juga sangat pelik. Dan tentunya hal ini juga untuk menemukan konsep atau rumusan pendidikan karakter yang sistematis dengan mengkaji dan mengoptimal educational institutions anak.

\section{METODE PENULISAN}

Penulisan ini menggunakan pendekatan kualitatif, dengan jenis penulisan perpustakaan (Library Research). Oleh karena itu, keseluruhan data diambil dari buku atau karya tulis yang berkaitan dengan pembahasan "Pendidikan Karakter". Adapun metode teknik analisis data yang digunakan adalah metode analisis kualitatif deskriptif, karena data yang diolah berupa data-data verbal yakni datadata tertulis seperti: buku-buku pendidikan karakter, pedoman kurikulum 2013 di lembaga formal, jurnal, artikel, koran daring (online) dan termasuk standar baku berupa produk undang-undang yang berkaitan dengan sistem pendidikan nasional terutama terkait langsung dengan dinamika kurikulum pendidikan karakter di Indonesia dari berbagai fase tentang peranan Educational Institutions dalam pendidikan karakter anak. 


\section{PEMBAHASAN}

\section{Reintegrasi Educational Institutions}

Apabila menilik sejarah, term pendidikan karakter pertama kali mulai diterapkan di negara Amerika. Penerapan pedidikan karakter di Amerika bermula dari isu moral yang muncul dan memiliki alasan tersendiri untuk dilaksanakan di sekolah-sekolah (Thomas Lickona, 1991). Sementara pendidikan karakter di Indonesia dalam lintas sejarah telah dicanangkan sejak tahun 1947, bersamaan dengan pemberlakukan kurikulum leer plan, artinya rencana pengajaran. Dengan hal ini, visi dan misi pendidikan menitikberatkan pada pembetukan karakter sisiwa mulai dikembangkan. Kemudian, berlanjut pada kuriulum Rencana Pelajaran 1947. Pada kurikulum ini secara substansial menekankan pad keutamaan pendidikan watak, cinta tanah air dan bermasyarakat. Selanjutnya pendidikan karakter dapat dilihat pada perubahan dan pengembangan kurikulum yang terjadi pada tahun 1952, dan pada tahun 1964 di penghujung pemerintahan Soekarno, kurikulum 1964 ini difokuskan pada pengembangan daya cipta, rasa, karsa, karya, dan moral (Pancawardhana). Kemudian mata pelajaran diklasifikasikan dalam lima kelompok bidang studi: moral, kecerdasan, emosional/artistik, keterampilan, dan jasmaniah. Berlanjut lagi pada perubahan kurikulum di tahun 1968, 1975, 1984, 1994, 2004 , 2006 dan KTSP. Dan puncak pendidikan karakter sangat terlihat jelas pada kurikulum 2013 (Kaimuddin, 2011).

Perlunya pendidikan karakter di sekolah sejalan dengan apa yang dikemukakan oleh Taku (Ekumoto dan Taylor Halstead, 2007) yang menurut keduanya, bahwa kurikulum pendidikan karakter di sekolah idealnya dalam proses pembelajarannya bukan hanya terkait pada hal-hal abstraks saja, melainkan harus mengena pada proses konteksnya seperti pada kegiatan sehari-hari yang terintegrasi dalam mata pelajaran (J. Mark Halstead and Monica J. Taylor, 2010).

Pada konteks perkembangan karakter, untuk berbagai aspek dan lembaga harus selalu bersinergi, karena dalam perspektif dunia perkembangan karakter, segala hal di sekitar anak baik lingkungan manusia (orang tua, saudara, teman) demografi, kultur dapat mempengaruhi perkembangan individu. Berbagai aspek perkembangan yang meliputi perkembangan fisik, intelektual, emosi, sosial dan moral berkembang secara bertahap dengan urutan tertentu dipengaruhi bukan hanya melalui pengasuhan dan pendidikan sekolah saja, tapi interaksi dengan lingkungan sosial juga memiliki pengaruh yang cukup besar (Rita Eka Izzaty, 2013). Akan sulit bahkan tidak akan bisa jika hanya satu lembaga atau satu lingkungan saja yang menjadi pusat pendidik karakter bagi seseorang. Karena pendidikan karakter adalah tanggung jawab bersama, baik anggota keluarga, teman, kerabat, guru dan tokoh agama memiliki peran dalam membentuk karakter seseorang (S. E. Oladipo, 2014). Jika digambarkan bagaimana pengaruh Educational Institutions terhadap karakter individu, maka dapat diilustrasikan sebagai berikut:

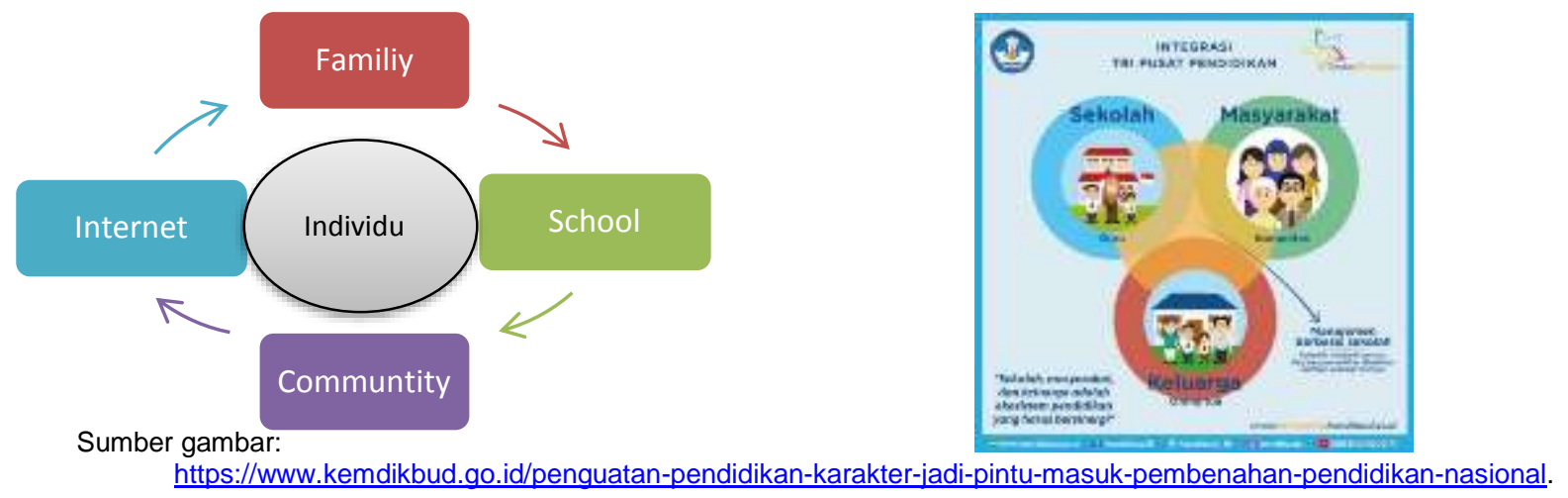


Melihat gambar di atas, maka dapat dikatakan bahwa Educational Institutions memilik pengaruh atau peran yang sama-sama besar. Dan tidak dapat dikatakan jika hanya satu atau dua saja yang memiliki pengaruh dan peran yang tiak signifikan dalam konteks perkembanan individu. Hal ini seperti apa yang telah diungkapkan oleh Jito subianto, yang dengan jelas memberikan pernyataan bahwa harus adanya sinergi antara semua lingkungan pendidikan, baik keluarga, sekolah dan masyarakat. Perihal ini sebagai langkah utama dan juga merupaka aturan dasar (basic rules) yang harus diterapakan dalam pendidikan karakter. Selain itu, ketiga institusi pendidikan ini meurutnya harus adanya keharmonisan dan kesinambungan satu sama lain untuk membentuk karakter siswa yang berkualitas (Jito Subianto, 2011).

Menindaklanjuti perkara ini Nasirudin juga menuturkan bahwa lembaga pendiidkan atau institusi pendidikan harus saling interdependensi atau saling bersinergi satu sama lain. Untuk melihat adanya sinergisitas antar ketiga lembaga tersebut, menurutnya dapat dilihat dari masing-masing peranan ketiga lembaga tersebut yaitu: keluarga sebagai model peranan. Dalam hal ini orang tua berperan dalam berbagai macam nilai kehidupan yang dapat diterima dan diaplikasikan oleh anak. Keteladanan orang tua merupakan faktor yang entitas bagi anak. Seperti berbicara, cara berpakaian, cara bertindak, dan lain-lain. dengan demikian, orang tua tetap menjadi pedoman bagi pembentukan nilai-nilai pada pola tingkah anak.

Peran sekolah: hal ini mengacu pada sekolah merupakan sarana yang secara sengaja dirancang untuk melaksanakan pendidikan. Demikian juga sekolah sebagai wadah yang strategis guna mendapatkan ilmu pengetahuan dan pembinaan kepribadian. Eksistensi dan peran sekolah tidak hanya untuk mendapatkan ilmu pengetahuan, sekolah juga harus membantu anak didik memahami nilai-nilai pendidikan karakter, mengadopsi atau memperaktikkannya untuk diri mereka sendiri, dan kemudian bertindak dalam kehidupan mereka sendiri (Nasiruddin, 2017).

Peran masyarakat: hal ini mengacu karena masyarakat merupakan bagian dari institusi pendidikan ketiga setelah keluarga dan sekolah. Pendidikan dalam masyarakat dampaknya lebih luas. Corak dan ragam pendidikan yang dialami seseorang dalam masyarakat banyak sekali, meliputi segala bidang, baik pembentukan kebiasaan-kebiasaan, pembentukan pengertian-pengertian (pengetahuan) sikap dan minat, maupun pembentukan kesusialaan dan keagamaan. Peran serta masyarakat dalam meningkatkan pendidikan karakter seperti: 1. Membiasakan gotong royong dilingkungan tempat anak tinggal, 2. Membiasakan anak tidak membuang sampah sembarangan, 3. Merusak atau mencoret coret fasilitas umum, 4 . Menegur anak yang melakukan perbuatan yang tidak baik, dan lain sebagainya. Denagan demikian, tentunya hal-hal seperti ini akan memberikan pengajaran nilai-nilai karakter kepada anak.

Melihat penjelasan di atas terkait sinergi antara keluarga, sekolah dan masyarakat, bahwa ketiga institusi pendidikan tersebut tidak dapat dipisahkan satu sama lain. Perihal ini mengacu pada pendidikan karakter yang berkualitas bila adanya sinegi atau keterkaitan antara ketiga isntitusi pendidikan tersebut.

\section{Grand Design Educational Institutions}

Setelah mengatahui fungsi dan peranan lembaga pendidikan anak yaitu keluarga, sekolah dan masyarakat. Maka akan dikaji satu per satu tentang grand design yang dibutuhkan pada saat ini yang menggunkaan pendekatan holistik dan komprehensif. 


\section{a. Educational Institutions of Family}

Keluarga merupakan salah sistem sosial yang terkecil dalam lingkungan sosial, yang pada umumnya terdiri dari ayah, ibu, dan anak. Perihal keluarga juga sebagai lembaga pendidikan pertama dan bagian utama dalam pendidikan anak. Maka, dapat dikatakan keluarga sebagai peletak dasar-dasar pendidikan dalam pembentukkan karakter anak. Karena hal ini pendidikan karakter yang positif terhadap anak sangat ditekankan dan diharuskan bagi keluarga, karena baik buruk seorang anak terkadang dapat dikenali dari latar belakang keluarga.

Keluarga merupakan salah satu institusi pendidikan. Setiap orang yang berada dalam institusi ini pasti akan mengalami perubahan dan perkembangan menurut warna dan corak institusi tersebut. Terkait perihal keluarga, Abd alRahman al-Naqib memberikan suatu formulasi yang jelas tentang tujuan pendidikan Islam. Di mana menurutnya, tujuan tersebut harus mencakup aspek yang universal seperti: fisik, akal dan karakter untuk mempersiapkan anak bisa hidup bermasyarakat (Abd Abd al-Rahman al-Naqib, 1984).

Pernyataan serupa oleh Abdurahman al-Nahlawi terkait formulasi dalam pendidikan Islam. al-Nalawi memandang kosep pendidikan Islam sangat relevan dengan perubahan zaman dan sangat universal, baik dari diemensi sosial, maupun dimensi psikologis. Kosep dari pendidikan Islam mewujudkan seluruh aspek ideal yang mencakup pemeliharaan seluruh aspek perkembangan, baik itu aspek material, spiritual, intelektual, prilaku sosial, apresiasi dan pengalaman (Abd al Rahma>n al-Nahlawi>, 1983).

Kemudian dalam pandangannya, pendidik yang pertama dalam memberikan ketiga aspek ini adalah orang tua. Hal ini terungkap dalam Al-Qur'an tentang kewajiban orang tua terhadap anak mereka. Firman Allah Swt. dalam surah Luqman Ayat 13- 17 terkandung di dalamnya baik secara ekspilisit maupun implisit tentang pendidikan akhlak (M. QuraishShihab, 2003). Firman Allah dalam Surah Luqman Ayat 13-17 Sebagai Berikut:

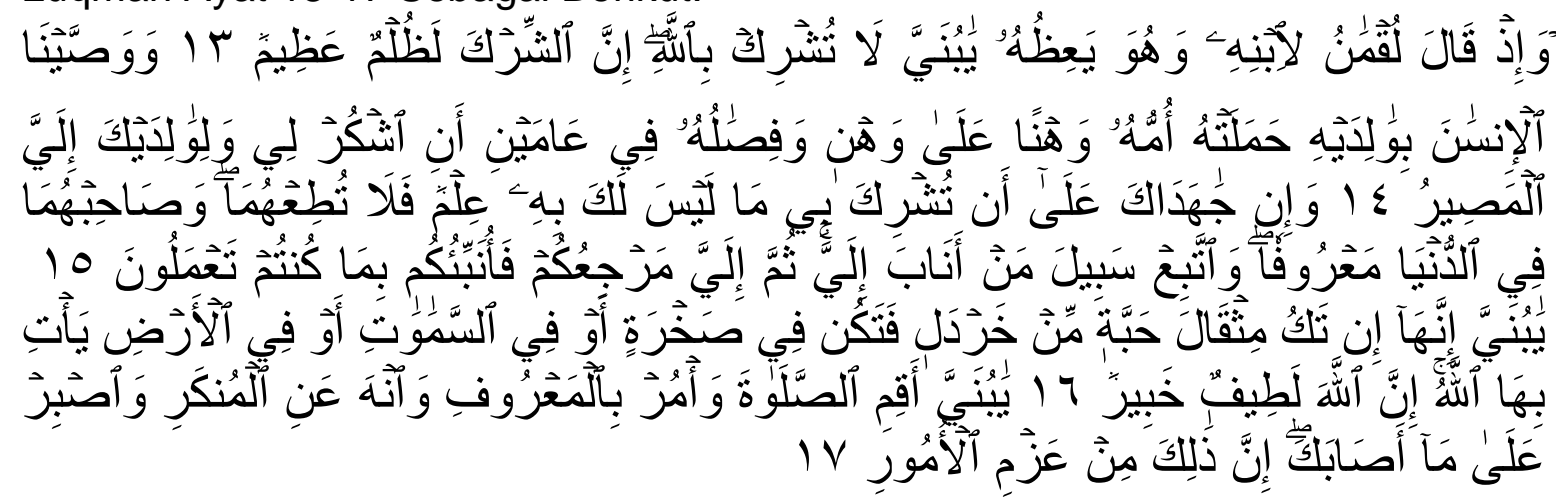

Artinya: "Dan (ingatlah) ketika Luqman berkata kepada anaknya, di waktu ia memberi pelajaran kepadanya: "Hai anakku, janganlah kamu mempersekutukan Allah, Sesungguhnya mempersekutukan (Allah) adalah benar-benar kezaliman yang besar". 14. dan Kami perintahkan kepada manusia (berbuat baik) kepada dua orang ibu- bapanya; ibunya telah mengandungnya dalam Keadaan lemah yang bertambah- tambah, dan menyapihnya dalam dua tahun. Bersyukurlah kepadaku dan kepada dua orang ibu bapakmu, hanya kepada-Kulah kembalimu.15. dan jika keduanya memaksamu untuk mempersekutukan dengan aku sesuatu yang tidak ada pengetahuanmu tentang itu, Maka janganlah kamu mengikuti keduanya, dan pergaulilah keduanya di dunia dengan baik, dan ikutilah jalan orang yang kembali kepada-Ku, kemudian hanya kepada-Kulah kembalimu, Maka Kuberitakan kepadamu apa yang telah kamu kerjakan.16. (Luqman berkata): "Hai anakku, 
Sesungguhnya jika ada (sesuatu perbuatan) seberat biji sawi, dan berada dalam batu atau di langit atau di dalam bumi, niscaya Allah akan mendatangkannya (membalasinya). Sesungguhnya Allah Maha Haluslagi Maha mengetahui.17. Hai anakku, dirikanlah shalat dan suruhlah (manusia) mengerjakan yang baik dan cegahlah (mereka) dari perbuatan yang mungkar dan bersabarlah terhadap apa yang menimpa kamu. Sesungguhnya yang demikian itu termasuk hal-hal yang diwajibkan (oleh Allah)." [Q.S Luqman: [31] 13-1731].

Dari ayat tersebut di atas sangat jelas, bahwa keluarga merupakan lembaga atau isntitusi pertama dalam memberikan pendidikan karakter anak. hal ini juga dapat dikaitkan dengan temuan David H. Elkind dan Freddy Sweet yang mengungkapkan bahwa peran keluarga dalam memberikan pengaruh karakter sosial anak sangat signifikan. Karena dalam pandangan keduanya, bahwa untuk menjadikan anak memiliki karakter sosial harus dengan melibatkan anak dalam aktivitas yang dapat membuat mereka berpikir keritis tentang persoalan moral dan etika, menjadikan mereka berkomitmen untuk bertindak bermoral dan beretika, dan memberi mereka banyak kesempatan untuk mempraktikkan nilai moral dan etika (David H. Elkind dan Freddy Sweet, 2015).

Melihat hal ini peran dan fungsi keluarga sangat jelas, karena hal ini dapat dipertegas oleh Thomas Lickona pada keterangnnya, bahwa jika karakter yang baik harus mencakup tiga domain karakter, yaitu pengetahuan moral, perasaan moral dan tindakan moral. Ketiga domain ini dapat ditumbuhkan oleh institusi keluarga, sekolah dan masyarakat yang saling bersinergi. Dan pada tataran praksisnya orang tua harus senantiasa memberikan teladan secara inklusif yang menjangkau ke luar rumah (Thomas Lickona, 2004).

Perihal tataran praksisnya, Muchlas Samani juga memberikan argumen bahwa terdapat beberapa langkah untuk menumbuhkan karakter sosial anak, yaitu, dengan memberikan pengetahuan moral kepada anak. Kemudian, setelah anak memiliki pengetahuan moral, orang tua hendaknya dapat menumbuhkan rasa keinginan untuk berbuat baik. Hal inilah yang akan membuat anak memiliki rasa cinta untuk berbuat kebaikkan (MuchlasSamani, 2013).

Menindaklanjuti perihal peranan dan pengaruh orang tua, Emillie Philips Smith turut berpendapat bahwa pengaruh orang tua sangatlah besar tarhadap bagaimana sikap dan mental seorang anak nantinya di masa depan. Orang tua yang secara proaktif terlibat dan mendidik dengan memberikan nilai-nalai ras, etnis pada anak mereka, maka diperdiksi anaknya juga akan lebih condong untuk bersikap positif, rasis, dan lebih sedikit untuk terlibat dalam pergaulan yang menyimpang (Emilie Phillips Smith and others, 2003).

Dari paparan di atas, terkait peranan dan fungsi institusi keluarga, dapat dipertegas jika keluarga sebagai isntitusi pendidikan pertama dalam memberikan pendidikan karakter terhadap anak. Dalam tataran paksisnya, pendidikan karakter yang diberikan oleh keluarga harus menyentuh semua aspek seperti, pengetahuan moral, perasaan dan tindakan moral. Menurut S. E. Oladipo dalam pendidikan moral anak, peran orang tua kebanyakan pada usia dini, dan telah mengembangkan komponen dasar pada kesadaran moral anak, seperti rasa emosianal, kemampuan untuk membedakan antara yang benar dan yang salah, serta kemampuan untuk peduli terhadap orang lain. Di antara periode ini adalah waktu yang baik untuk meletakkan dasar moral yang kuat pada anak. Dan pendidik yang paling cocok untuk pekerjaan ini adalah orang tua (S. E. Oladipo, 2009).

\section{b. Educational Institutions of School}

Institusi pendidikan, terutama pendidikan formal bertanggung jawab atas pendidikan karakter. Alasannya, institusi pendidikan formal merupakan wadah yang 
yang sistematis dan teroganisir untuk membimbing, mengarahkan, mendidik, dan membelajarkan generasi bangsa teritama genarasi melenial saat ini. Sekolah atau perguruan tinggi memiliki pengaruh dan dampak terhadap karakter siswa atau mahasiswa, baik disengaja maupun tidak. Selain itu, Secara substansial, pendidikan karakter telah diamanatkan pada penjelasan tentang Fungsi dan Tujuan Pendidikan Nasional dalam UU 20 Tahun 2003 BAB II pasal 3, di mana pada undang-undang ini telah meletakkan pondasi dan mengarahkan penyelenggaraan pendidikan berorientasi pada pembentukan karakter peserta didik (Kaimuddin, 2014).

Atas amanat itu, pendidikan berbasis karakter diyakini perlu dan urgen dalam sistem pendidikan nasional. Adapun urgensi-urgensi tentang perlunya pendidikan karakter tersebut yakni; 1) lembaga pendidikan merupakan wadah formal yang teroganisir dan substansial untuk menghasilkan generasi penerus bangsa berkarakter. Generasi bangsa berkarakter menjadikan bangsa jaya dan bermartabat; 2) lembaga pendidikan merupakan peletak persemaian dan transformasi nilai-nilai luhur budaya bangsa dalam membangun integritas keperibadian dan memperkokoh identitas diri peserta didik. Lembaga pendidikan menjadi wadah tumbuhnya semangat patriotisme, nasionalisme, dan rasa kecintaan yang kuat sebagai anak bangsa; 3) Lembaga pendidikan merupakan tempat mendidik generasi bangsa yang berakhlak mulia dan bermartabat. Ungensiurgensi inilah menjadi entry point untuk menyatakan bahwa sekolah atau kampus mempunyai tugas dan tanggung jawab untuk melakukan pendidikan moral dan pembentukan karakter (Kaimuddin, 2014).

Terkait aktualisasi pendidikan karakter, maka pendidikan nasional saat ini sudah sangat kental dengan nuansa pendidikan karakter, khususnya pada kurikulum 2013 yang diterapkan pada saat ini. Pendidikan nasional ditujukan salah satunya untuk mengembangkan berbagai kecerdasan kecerdasan. Seperti kecerdasan akademik melalui pendidikan disiplin ilmu. Filosofi ini yang menurut Kaimuddin menentukan bahwa isi kurikulum adalah disiplin ilmu dan pembelajaran adalah pembelajaran disiplin ilmu. Dengan demikian, dapat dipahami bahwa kurikulum 2013 menggunakan filosofi dalam mengembangkan kehidupan individu peserta didik dalam beragama, seni, dan kretivitas, berkomunikasi, nilai dan berbagai dimensi intelegensi yang sesuai dengan diri seorang peserta didik dan diperlukan masyarakat, bangsa, dan ummat manusia (Kaimuddin, 2014). Kaimuddin juga mengatakan bahwa pada kurikulum 2013 saat sudah menununjukkan penekanan pendidikan karakter yang sudah terlihat pada kerangka aspek-aspek kerangka dasar seperti pada aspek filosofi, yuridis, empiris, sosiologis dan psikilogis. Hal ini tergambar pada karakteristik kurikulum 2013 sebagai berikut: a. Mengembangkan keseimbangan antara pengembangan sikap spiritual dan sosial, rasa ingin tahu, kreativitas, kerja sama dengan kemampuan intelektual dan psikomotorik;

b. Sekolah merupakan bagian dari masyarakat yang memberikan pengalaman belajar yang terencana dimana peserta didik menerapkan apa yang dipelajari di sekolah ke masyarakat dan memanfaatkan masyarakat sebagai sumber belajar;

c. Mengembangkan sikap, pengetahuan, dan keterampilan serta menerapkannya dalam berbagai situasi di sekolah dan masyarakat;

d. Memberi waktu yang cukup leluasa untuk mengembangkan berbagai sikap, pengetahuan, dan keterampilan; 
e. Kompetensi dinyatakan dalam bentuk kompetensi inti kelas yang dirinci lebih lanjut dalam kompetensi dasar mata pelajaran;

f. Kompetensi inti menjadi unsur pengorganisasian (organizing elements) kompetensi dasar, dimana semua kompetensi dasar dan proses pembelajaran dikembangkan untuk mencapai kompetensi yang dinyatakan dalam kompetensi inti;

g. Kompetensi dasar yang dikembangkan didasarkan pada prinsip akumulatif, saling memperkuat (enforced) dan memperkaya (enriched) antar mata pelajaran dan jenjang pendidikan (organisasi vertikal dan horizontal (Kaimuddin, 2014).

DIMENSI PENGETAHUAN

\begin{tabular}{|c|c|c|}
\hline $\begin{array}{l}\text { SD/MI/SDLB/ } \\
\text { Paket A }\end{array}$ & $\begin{array}{c}\text { SMP/MTs/SMPLB/ } \\
\text { Paket B }\end{array}$ & $\begin{array}{l}\text { SMA/MA/SMALB/ } \\
\text { Paket C }\end{array}$ \\
\hline \multicolumn{3}{|c|}{ RUMUSAN } \\
\hline $\begin{array}{l}\text { Memiliki pengetahuan } \\
\text { faktual, konseptual, } \\
\text { prosedural, dan } \\
\text { metakognitif pada } \\
\text { tingkat dasar } \\
\text { berkenaan dengan: } \\
\text { 1. ilmu pengetahuan, } \\
\text { 2. teknologi, } \\
\text { 3. seni, dan } \\
\text { 4. budaya. } \\
\text { Mampu mengaitkan } \\
\text { pengetahuan di atas } \\
\text { dalam konteks diri } \\
\text { sendiri, keluarga, } \\
\text { sekolah, masyarakat } \\
\text { dan lingkungan alam } \\
\text { sekitar, bangsa, dan } \\
\text { negara. }\end{array}$ & $\begin{array}{l}\text { Memiliki pengetahuan } \\
\text { faktual, konseptual, } \\
\text { prosedural, dan } \\
\text { metakognitif pada } \\
\text { tingkat teknis dan } \\
\text { spesifik sederhana } \\
\text { berkenaan dengan: } \\
\text { 1. ilmu pengetahuan, } \\
\text { 2. teknologi, } \\
\text { 3. seni, dan } \\
\text { 4. budaya. } \\
\text { Mampu mengaitkan } \\
\text { pengetahuan di atas } \\
\text { dalam konteks diri } \\
\text { sendiri, keluarga, } \\
\text { sekolah, masyarakat } \\
\text { dan lingkungan alam } \\
\text { sekitar, bangsa, } \\
\text { negara, dan kawasan } \\
\text { regional. }\end{array}$ & $\begin{array}{l}\text { Memiliki pengetahuan } \\
\text { faktual, konseptual, } \\
\text { prosedural, dan } \\
\text { metakognitif pada } \\
\text { tingkat teknis, spesifik, } \\
\text { detil, dan kompleks } \\
\text { berkenaan dengan: } \\
\text { 1. ilmu pengetahuan, } \\
\text { 2. teknologi, } \\
\text { 3. seni, } \\
\text { 4. budaya, dan } \\
\text { 5. humaniora. } \\
\text { Mampu mengaitkan } \\
\text { pengetahuan di atas } \\
\text { dalam konteks diri } \\
\text { sendiri, keluarga, } \\
\text { sekolah, masyarakat } \\
\text { dan lingkungan alam } \\
\text { sekitar, bangsa, } \\
\text { negara, serta kawasan } \\
\text { regional } \\
\text { dan internasional. }\end{array}$ \\
\hline
\end{tabular}

Istilah pengetahuan Faktual, Konseptual, Prosedural, dan Metakognitif pads masing-masing satuan pendidikan dijelaskan pada matriks berikut.

\begin{tabular}{|c|c|c|c|}
\hline PENJELAEAN & $\begin{array}{l}\text { SDD/MI/BDLE/ } \\
\text { Maket A }\end{array}$ & 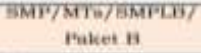 & 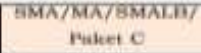 \\
\hline Fubtual & 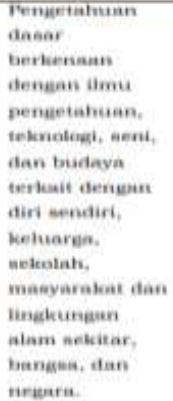 & 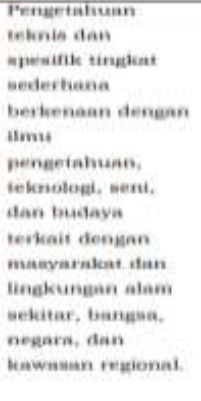 & 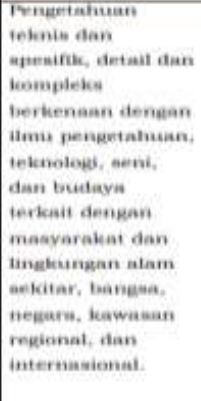 \\
\hline Meneeptual & 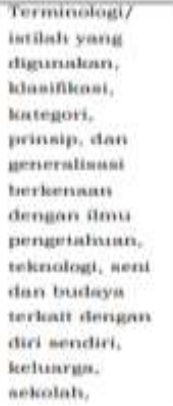 & 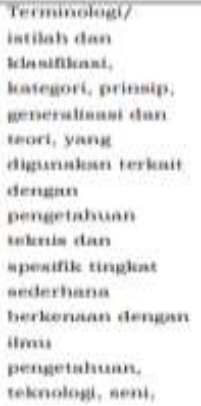 & 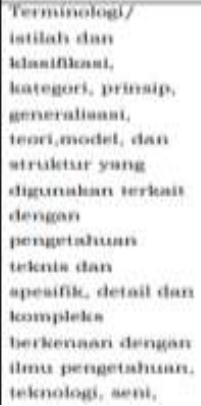 \\
\hline
\end{tabular}

Setiap lulusan satuan pendidikan dasar dan menengah memiliki kompetensi pada tiga dimensi yaitu sikap, pengetahuan, dan keterampilan.

Lulusan SD/MI/SDLB/Paket A; SMP/MTs/SMPLB/Paket B; dan SMA/MA/ SMALB/Paket C memiliki kompetensi pada dimensi sikap sebagai berikut.

\begin{tabular}{|c|c|c|}
\hline $\begin{array}{l}\text { SD/MI/SDLB/ } \\
\text { Paket A }\end{array}$ & $\begin{array}{l}\text { SMP/MTs/SMPLB/ } \\
\text { Paket B }\end{array}$ & $\begin{array}{l}\text { SMA/MA/SMALB/ } \\
\text { Paket C }\end{array}$ \\
\hline \multicolumn{3}{|c|}{ RUMUSAN } \\
\hline $\begin{array}{l}\text { Memiliki perilaku yang } \\
\text { mencerminkan sikap: } \\
\text { 1. beriman dan } \\
\text { bertakwa kepada } \\
\text { Tuhan YME, } \\
\text { 2. berkarakter, jujur, } \\
\text { dan peduli, } \\
\text { 3. bertanggungjawab, } \\
\text { 4. pembelajar sejati } \\
\text { sepanjang hayat, dan } \\
\text { 5. sehat jasmani dan } \\
\text { rohani } \\
\text { sesuai dengan } \\
\text { perkembangan anak di } \\
\text { lingkungan keluarga, } \\
\text { sekolah, masyarakat dan } \\
\text { lingkungan alam sekitar, } \\
\text { bangsa, dan negara. }\end{array}$ & $\begin{array}{l}\text { Memiliki perilalu yang } \\
\text { mencerminkan sikap: } \\
\text { 1. beriman dan } \\
\text { bertakwa kepada } \\
\text { Tuhan YME, } \\
\text { 2. berkarakter, jujur, } \\
\text { dan peduli, } \\
\text { 3. bertanggungjawab, } \\
\text { 4. pembelajar sejati } \\
\text { sepanjang hayat, dan } \\
\text { 5. sehat jasmani dan } \\
\text { rohani } \\
\text { sesuai dengan } \\
\text { perkembangan anak di } \\
\text { lingkungan keluarga, } \\
\text { sekolah, masyarakat dan } \\
\text { lingkingan alam sekitar, } \\
\text { bangsa, negara, dan } \\
\text { kawasan regional. }\end{array}$ & $\begin{array}{l}\text { Memiliki perilaku yang } \\
\text { mencerminkan sikap: } \\
\text { 1. beriman dan } \\
\text { bertakwa kepada } \\
\text { Tuhan YME, } \\
\text { 2. berkarakter, jujur, } \\
\text { dan peduli, } \\
\text { 3. bertangungiawab, } \\
\text { 4. pembelajar sejati } \\
\text { sepanjang hayat, } \\
\text { dan } \\
\text { 5. sehat jasmani dan } \\
\text { rohani } \\
\text { sesuai dengan } \\
\text { perkembangan anak di } \\
\text { lingkungan keluarga, } \\
\text { sekolah, masyarakat } \\
\text { dan lingkungan alam } \\
\text { sekitar, bangsa, negara, } \\
\text { kawasan regional, dan } \\
\text { internasional. }\end{array}$ \\
\hline
\end{tabular}

Lulusan SD/MI/SDLB/Paket A; SMP/MTs/ SMPLB/Paket B; dan SMA/MA/ SMALB/Paket C memiliki kompetensi pada dimensi pengetahuan sehagai

\begin{tabular}{|c|c|c|c|}
\hline PENJELASAN & $\begin{array}{l}\text { SD/MI/SDLB/ } \\
\text { Paket A }\end{array}$ & $\begin{array}{c}\text { SMP/MTs/SMPLB } / \\
\text { Paket B }\end{array}$ & $\begin{array}{c}\text { SMA/MA/SMALB } \\
\text { Paket C }\end{array}$ \\
\hline & $\begin{array}{l}\text { sendiri dan } \\
\text { menggunakanny } \\
\text { a dalam } \\
\text { mempelajari } \\
\text { ilmu } \\
\text { pengetahuan, } \\
\text { teknologi, seni } \\
\text { dan budaya } \\
\text { terkait dengan } \\
\text { diri sendiri, } \\
\text { keluarga, } \\
\text { sekolah, } \\
\text { masyarakat dan } \\
\text { lingkungan alam } \\
\text { sekitar, bangsa } \\
\text { dan negara. }\end{array}$ & $\begin{array}{l}\text { menggunakannya } \\
\text { dalam } \\
\text { mempelajari } \\
\text { pengetahuan } \\
\text { teknis dan } \\
\text { spesifik tingkat } \\
\text { sederhana } \\
\text { berkenaan dengan } \\
\text { ilmu } \\
\text { pengetahuan, } \\
\text { teknologi, seni, } \\
\text { dan budaya } \\
\text { terkait dengan } \\
\text { masyarakat dan } \\
\text { lingkungan alam } \\
\text { sekitar, bangsa, } \\
\text { negara, dan } \\
\text { kawasan regional }\end{array}$ & $\begin{array}{l}\text { menggunakannya } \\
\text { dalam } \\
\text { mempelajari } \\
\text { pengetahuan } \\
\text { teknis, detail, } \\
\text { spesifik, } \\
\text { kompleks, } \\
\text { kontekstual dan } \\
\text { kondisional } \\
\text { berkenaan dengan } \\
\text { ilmu pengetahuan, } \\
\text { teknologi, seni, } \\
\text { dan budaya } \\
\text { terkait dengan } \\
\text { masyarakat dan } \\
\text { lingkungan alam } \\
\text { sekitar, bangsa, } \\
\text { negara, kawasan } \\
\text { regional, dan } \\
\text { internasional. }\end{array}$ \\
\hline
\end{tabular}

Lulusan SD/MI/SDLB/Paket A; SMP/MTs/SMPLB/Paket B; dan SMA/MA/ SMALB/Paket C memiliki kompetensi pada dimensi keterampilan sebagai berikut. 
Melihat dari lampiran Permendikbud No. 21 tentang standar kelulusan tingkat dasar dan menengah, bahwa Kurikulum 2013 dikembangkan berdasarkan teori "pendidikan berdasar standar" (standard-based education) dan teori "kurikulum berbasis kompetensi "(competence-based curriculum). Pendidikan berdasarkan standar menetapkan adanya standar nasional sebagai kualitas minimal warga negara yang dirinci menjadi standar isi, standar proses, standar kompetensi lulusan, standar pendidik dan kependidikan, standar sarana dan prasarana, standar pengelolaan, standar pembiayaan, dan standar penilaian pendidikan. Kurikulum berbasis kompetensi dirancang untuk memberikan pengalaman belajar seluas-luasnya bagi peserta didik dalam mengembangkan kemampuan untuk bersikap, berpengetahuan, keterampilam, dan bertindak. Kurikulum 2013 menganut : (1) pembelajaran yang dilakukan guru (taught curriculum) dalam bentuk proses yang dikembangkan, berupa kegiatan pembelajaran di sekolah, kelas, dan masyarakat; (2) pengalaman belajar langsung perserta didik (learned curriculum) sesuai dengan latar belakang, karakteristik, dan kemampuan awal peserta didik (Permendikbud No. 21 Tahun 2016).

Lebih lanjut terkait pendidikan karakter yang tertuang dalam kurikulum 2013, bahwa, menurut Sri Haryati dalam studinya menyatakan jika tujuan kurikulum 2013 adalah mengubah sikap pembelajar atau siswa dapat menjadi siswa yang memiliki sikap yang benar-benar tertanam dalam diri siswa, melalui nilai-nilai pendidikan karakter yang terkandung di dalamnya. Dengan demikian, jika memiliki sikap dan mental yang terpuji maka pembelajar akan mampu menyerap ilmu dengan baik dan tentu menjadi generasi yang bersih. Lebih lanjut dalam penuturan Sri Haryati, bahwa pendekatan dan pembelajaran dalam kurikulum 2013 harus mengembangkan ranah sikap, pengetahuan, dan keterampilan dengan lintasan perolehan yang bertahap. Keterangan selanjtnya, menurut Sri, pada tataran praktis, kegiatan belajar mengajar di dalam kelas, sikap diperoleh melalui aktivitas menerima, menjalankan, menghargai, menghayati, dan mengamalkan (Sri Haryati, 2013).

Berlanjut pada tahap pengembangan pengetahuan. Di mana pengetahuan dapat diperoleh melalui aktivitas mengingat, memahami, menerapkan, menganalisis, mengevaluasi, dan mencipta. Sementara, pada aspek atau sikap keterampilan melalui aktivitas mengamati, menanya, mencoba, menalar, menyajikan, dan mencipta. Tahap-tahap belajar dan mengajar itu sarat dengan pendidikan karakter yang harus selalu diaplikasikan dalam setiap pembelajaran di dalam kelas. Untuk mendapatkan konsep tertentu, siswa harus melakukan proses yang panjang. Begitu pula guru harus mampu mengendalikan diri untuk tidak segera memberitahu dan harus sabar untuk memberi kesempatan siswa.

Sri juga memberikan pernyataan bahwa, pendekatan yang saat ini diterapkan dalam pendidikan karakter, menjadikan guru sebagai mediator, ekplorator, dan fasilitator bagi pembelajar atau siswa. Pedekatan dalam pembelajaran kurikulum 2013 saat ini yang sedang diterapakan dikenal juga dengan pendekatan siantifik, yang pada esensi kegiatan pembelajaran menekankan pada lima aspek (5 M) yaitu mengamati, menanya, menggali informasi, menalar, dan mengomunikasikan (Sri Haryati, 2013). Dapat dipahami dari pernyataan Sri Haryati tersebut, bahwa dalam kurikulum 2013 saat ini yang 
sedang dijalankan, adanya penekanan pendidikan karakter yang benar-benr harus terlaksana dalam setiap pembelajaran. Bahkan, bukan hanya pada tataran pendidikankurikuler, melainkan juga pada pendidikan ekstra-kurikuler dan kokurikuler. Guru memiliki peranan yang sangat signifikan dalam memberikan pembelajaran dan teladan nilai-nilai karakter di sekolah.

Berlanjut pada keterangan yang diberikan oleh Matthew Davidson dan Thomas Lickona terkait sekolah juga sebagai penanggung jawab pendidikan karakter. Keduanya memberikan empat argumen tentang pendidikan karakter dapat meningkatkan prestasi dan perubahan prilaku anak di sekolah, yaitu:

1. Siswa membutuhkan perilaku berkarakter yang harus dikembangkan oleh sekolah baik dari aspek kognitif, afektif dan psikomotrik.

2. Siswa mengembangkan karakternya seperti kemampuan kerja keras, menyingkirkan tantangan, dan menikmati tugasnya sebagai tanggung jawab mereka di sekolah.

3. Siswa membutuhkan karakter bermoral seperti rasa hormat, kejujuran, keramahan, dan ketulusan hati untuk menciptakan hubungan di ruang kelas yang membuat lingkungan belajar positif.

4. Siswa mengembangkan karakter bermoral dari lingkungan sekolahnya seperti membantu sesama teman untuk mengerjakan tugas, mengkaji isuisu moral dalam kurikulum, dan menggunakan pembelajaran kurikuler untuk membantu memecahkan masalah hidup yang sesungguhnya (Matthew Davidson and Thomas Lickona).

Dapat dipahami dari beberapa alasan tersebut, bahwa pendidikan karakter di sekolah sangat diharapkan guna dapat mengembangkan karakter positif dan semua potensi yang dimilik oleh anak. Pihak guru, dan sivitas sekolah saling bersinergi dalam memberikan pendidikan dan teladan karakter positif terhadap anak.

Kemudian, di kalangan pemikir muslim terdapat penegasan yang sama, seperti Ikhwa $>n$ al-Shafa $>$ yang dikaji oleh Na>diyah Jama $>$ I al-Di>n mengungkapkan bahwa tujuan mendasar pendidikan Islam adalah membentuk manusia yang baik dengan kualitas karakter yang baik juga (Nadiyah Jamal alDin, 1983). Terdapat dalil Al-Qur'an yang menjelaskan tentang ketiga aspek dalam komponen karakter yaitu, aspek kognitif, afek dan psikomotorik dalam surah An-Nahl ayat 78. Firman Allah Swt dalam surah An-Nahl Ayat 78:

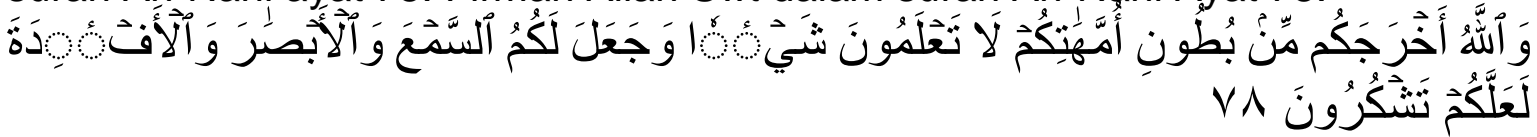

Artinya: "Dan Allah mengeluarkan kamu dari perut ibumu dalam Keadaan tidak mengetahui sesuatupun, dan Dia memberi kamu pendengaran, penglihatan dan hati, agar kamu bersyukur." [QS. An-Nahl [16]: 78]

Dalam hal menumbuhkan dan memberi pengajaran tentang pengetahuan nilai moral, hendaknya guru menerapkan 3C (mengingat, memahami, dan mengaplikasikan), tentang teori-teori nilai atau juga disebut dengan pengajaran nilai (teaching or value). Metode lain yang bisa digunkaan oleh guru yaitu, pembelajaran diskusi. Anak-anak berdiskusi tentang peristiwa-peristiwa konkret yang melibatkan isu nilai yang dapat meningkatkan kognisi nilai-nilai pada tataran aplikasi (Dharma Kesuma dkk, 2012).

Kemudian dalam hal menumbuhkan rasa empati, guru harus melatih dan membimbing murid untuk melakukan empati. Selain itu, guru juga dapat mengajar sikap toleransi kepada murid agar murid dapat merasakan apa yang orang lain 
rasakan. Dengan melakukan hal-hal tersebut, sikap empati akan benar-benar dilakukan oleh murid baik di sekolah maupun di luar sekolah (Dharma Kesuma dkk, 2012).

Terlihat dari penjelasan penulis di atas, dapat disimpulkan bahwa sekolah merupakan lembaga pendidikan moral anak setelah keluarga, dan disebut juga sebagai lembaga sekunder yang memainkan peranan penting, bertujuan membentuk perkembangan paripurna dalam aspek fisik, akal dan moral (karakter) untuk mempersiapkan siswa hidup sukses dan bermasyarakat.

Kompetensi moral adalah kemampuan untuk mengubah penilaian dan perasaan moral ke dalam tindakan moral yang efektif. Untuk memecahkan suatu konflik dengan adil, contohnya seseorang membutuhkan keahlian praktis mendengarkan, menyampaikan sudut pandang seseorang tanpa mencemarkan nama baik orang lain, dan mengusahakan solusi yang dapat diterima semua pihak (Thomas Lickona, 1991). Munurut Nucci dalam Schwartz tindakan moral tidak hanya mengacu kepada tindakan dan kebiasaan seseroang saja, tapi disertai dengan emosi dan pilihan moral (Larry Nucci dalam Merle J. Schwartz, 2007).

Terdapat tiga model dasar dalam memberikan pelatihan untuk mengembangkan kompetensi moral. Pertama, hendaknya sekolah menyediakan kesempatan-kesempatan bagi siswa terlibat dan mengaplikasikan tindakan moral, seperti siswa belajar menghargai dan membantu temannya ketika mengalami kesusahan. Kedua, guru memberikan teladan dan menunjukan kepada murid bagaimana karakter yang baik, seperti ketika murid memiliki keinginan untuk melanggar peraturan sekolah, maka guru harus memberikan nasihat dan menjelaskan bahwa itu perbuatan yang tidak baik. Contoh lain, seperti ketika guru memberikan contoh bagaimana meminta maaf jika melakukan kesalahan. Ketiga, guru mengusahakan kesempatan-kesempatan untuk pembelajaran kontekstual di dalam kelas (Larry Nucci dalam Merle J. Schwartz, 2007).

Keinginan moral adalah suatu perggerakan energi moral untuk melakukan apa yang dipikirkan harus dilakukan. Ada beberapa keinginan yang harus ada dalam diri seseorang, seperti keinginan untuk menjaga emosi di bawah kendali pemikiran, keinginan untuk melihat dan berpikir melalui seluruh dimensi moral dalam situasi, serta keinginan untuk melaksanakan tugas sebelum memperoleh kesenangan, dan terkhir keinginan untuk menolak godaan untuk menentang tekanan teman sebaya, dan melawan hawa nafsu. Semua ini merupakan inti dari dorongan moral (Thomas Lickona, 1991). Dengan adanya keinginan atau dorongan moral seperti ini, sesorang akan berupaya memiliki kemauan tindakan moral, konsisten untuk melakukan kawajiban moral, berbuat adil dan memiliki sikap disiplin untuk tindakan moral (Larry Nucci dalam Merle J. Schwartz, 2007).

Kebiasaan merupakan tindakan yang sebenarnya tanpa adanya tekanan untuk melakukan hal-hal yang baik. Orang-orang yang memiliki karakter baik, bertindak yang sebenarnya, dengan loyal, berani, baik, dan adil tanpa merasa tertekan oleh arah tindakan sebaliknya, seseorang melakukan semua ini karena dorongan kebiasaan. Apabila seseorang telah memiliki kebiasaan yang baik, maka manfaatnya akan dirasakan oleh diri sendiri, orang lain, bahkan ketika sedang menghadapi situasi yang berat (Thomas Lickona, 1991).

Terlihat dari penjelasan penulis di atas tentang kompenen-komponen yang terdapat dalam karakter yang baik, dapat disimpulkan bahwa semua komponen ini harus bersinergi dan saling mendukung satu sama lain agar anak benar-benar menjadi pribadi yang memiliki karakter baik (good character). Dalam hal membentuk karakter di sekolah yang perlu dikembangkan adalah memberikan perasaan dan tidakan moral di dalam setiap aspek pembelajaran dan dalam 
kegiatan sehari-hari di sekolah dan guru dan semua stakeholder sekolah harus terlibat dalam memberikan pendidikan karakter terhadap anak.

Selain itu, ada beberapa hal dalam mengajarkan pendidkan karakter agar dapat menyentuh aspek pengetahuan, perasaan dan tindakan moral, yaitu pertama, pembelajaran mental (berbasis otak) yang terdiri dari pengingatan fakta tentang kajadian atau peristiwa etik. Kedua, Pembelajaran jasmani melalui pengalaman lansung (hands-on experience), melibatkan seluruh pancaindra, melibatkan hampir seluruh sistem saraf. Ketiga, pembelajaran emosi dan subliminal (di bawah ambang persepsi sadar), melibatkan siswa untuk mempraktikan lansung tentang bagaimana jika merasa gembira, takut sedih, sayang, cinta peduli, euforia dan merasa gembira yang meluap-luap (Merle J. Schwartz, 2007).

Beberapa cara ini diyakini dapat menjadikan anak-anak benar-benar memiliki karakter yang baik. Selain itu, sekolah dan guru harus bisa memberikan arahan, pembiasaan dan pengajaran agar semua indikator-indikator dalam aspek tindakan moral ini benar-benar bisa diaplikasikan siswa dalam kehidupan sehari-hari.

\section{c. Educational Institutions of Environment}

Selain sekolah, lembaga seperti masyarakat juga berperan penting dalam pembentukan nilai dan karakter bagi anak. Pengaruh-pengaruh kultural dan masyarakat sekitar relevan sebagai faktor yang berpengaruh dalam pembentukan perilaku anak. Misalnya ketersediaan lapangan bermain, kehidupan bertetangga yang aman, sumber daya masyarakat, dan lembaga formal dan informal, yang memadai.

Masyarakat atau lingkungan sosial sangat memiliki pengaruh terhadap sikap seseorang. Seperti ketika anak-anak berinteraksi dengan masyarakat yang menunjukan sikap rasial dan memberikan support terhadap kegiatan anak, maka secara tidak lansung juga kan memberikan pengaruh terhadap sikap rasial dan prestasi akademik seorang anak (Emilie Phillips Smith and others, 2003). Masyarakat juga sebagai pergaulan sesama manusia dan menerapkan lapangan pendidikan yang luas dan meluas.

Kemudian dalam hubungannya dengan pendidikan karakter dapat dijelaskan bahwa masyarakat adalah kelompok sosial antar manusia yang tinggal di suatu tempat mempunyai tujuan tertentu, serta mempunyai norma yang disepakati bersama. Individu yang secara aktif terlibat dalam kegiatan masyarakat, seperti sering terlibat dalam kegiatan organisasi, berpatisipasi dalam kegiatan keagamaan serta terlibat dalam acara terstruktur dalam masyarakat, akan lebih sedikit waktu untuk melakukan hal-hal yang negatif (Peterson Buser C.H. and N.G. Westburg, 2010). Hal ini menandakan adanya lingkungan masyarakat yang baik, memberikan teladan, serta adanya dukungan terhadapaktivitas-aktivitas positif terhadap anak (Emilie Phillips Smith and others, 2014). Dampak positif dari keterlibatan lingkungan masyarakat ini akan memberikan pengaruh yang positif juga terhadap karakter anak (Christina Hamme Peterson an others, 2010).

Ulfah Fajarini juga memaparkan bahwa peran serta masyarakat dalam pendidikan karakter terlihat juga dalam revitalisasi kearifan lokal dalam merespons berbagai persoalan akut yang dihadapi bangsa dan negara, seperti korupsi, kemiskinan, dan kesenjangan sosial, hanya akan berjalan jika didukung oleh kebijakan negara yang disertai dengan keteladanan. Tanpa kedua hal tersebut, kearifan lokal hanya merupakan aksesori budaya yang tidak bermakna. Kearifan lokal di berbagai daerah pada umumnya mengajarkan budaya malu (jika berbuat salah). Akan tetapi, dlihat pada relitas sekarang, budaya malu seolah telah luntur. Peraturan yang adapun kadang-kadang memberi peluang kepada seorang terpidana atau bekas terpidana untuk menduduki jabatan publik. Karena itu, budaya 
malu sebagai bagian dari kearifan lokal semestinya dapat direvitalisasi untuk memerangi korupsi, apalagi dalam agamapun dikenal konsep halal-haram (uang yang diperoleh dari korupsi adalah haram) (Ulfah Fajarini, JurnalFakultas Tarbiyah Universitas Islam Negeri (UIN) Syarif Hidayatullah Jakarta)

Pada tataran ini kegiatan partisipasi masyarakat masih lebih dipahami sebagai upaya mobilasasi untuk kepentingan pemerintahan atau negara. Partisipasi tersebut idealnya berarti masyarakat ikut menentukan kebijakan pemerintah dan ikut serta dalam pendidikan, yaitu sebagai bagian dari kontrol masyarakat terhadap kebijakankebijakan. Dalam implementasi partisipasi masyarakat, seharusnya anggota masyarakat merasa bahwa tidak hanya menjadi objek dari kebijkan pemerintah, tetapi harus dapat mewakili masyarakat itu sendiri sesuai dengan kepentingan mereka. Perwujudan partisipasi masyarakat dapat dilakukan, baik secara individu atau kelompok, bersifat spontan atau terorganisasi, secara berkelanjutan, serta dengan cara-cara tertentu dapat dilakukan (Partisipasi Masyarakat dalam Pendidikan).

Secara eksplisit Abdul Majid memberikan penjelasan terkait peran serta masyarakat dalam pendidikan karakter. Menurutnya masyarakat memiliki peran yang trategis. Karena, implementasi pendidikan karakter harus ditopang oleh pilar yang kuat, dan pendidikan juga merupakan bagian integral dari keseluruhan tatanan sistem pendidikan nasional. Maka, harus dikembangkan dan dilaksanakan secara sistematik dan holistik dalam tiga pilar nasional yaitu, satuan pendidikan nasional, keluarga dan masyarakat. Masyarakat juga bisa disebut dengan komunitas, masyarakat lokal atau bangsa da negara (Abdul Majid dan Dian Andrayani, 2011).

Peran serta masyarakat dalam pendidikan karakter bisa dengan melalui habituasi. Habituasi dalam hal ini melalui proses penciptaan beragam situasi dan kondisi persistent-life condition yang berisi aneka pengetahuan (reinforcement) yang memungkinkan perserta didik pada satuan pendidikannya, di keluarga, dan di lingkungan masyarakat membiasakan dari berperilaku sesuai nilai dan menjadikan perangkat nilai yang telah diinternalisasikan melalui proses oleh hati, oleh pikir, rasa dan oleh raga (Abdul Majid dan Dian Andrayani, 2011). Terdapat dalil Alquran yang menerangkan peran serta masyarakat dalam pendidikan karakter. Di antara dalil tersebut adalah surat Al-Maidah ayat 6. Surat Al-Maidah Ayat 2:

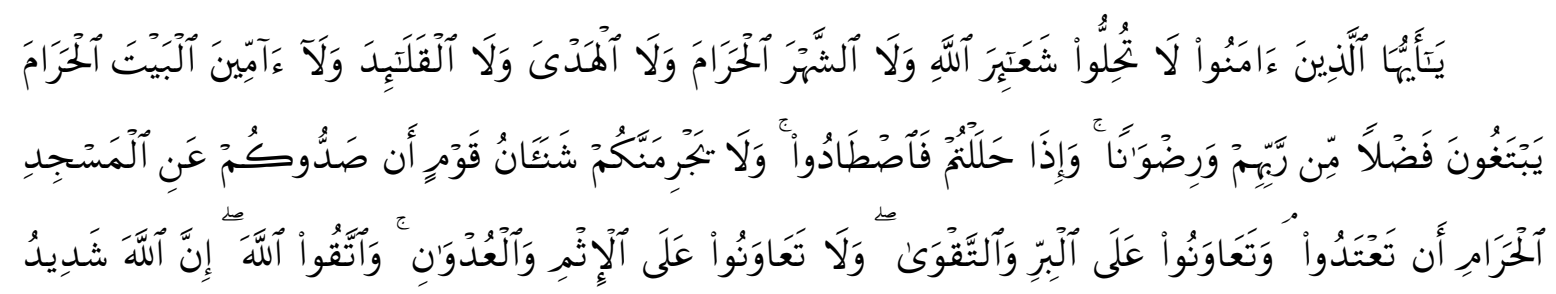
آلَّعَقَابِ

"Hai orang-orang yang beriman, janganlah kamu melanggar syi'ar-syi'ar Allah [389], dan jangan melanggar kehormatan bulan-bulan haram[390], jangan (mengganggu) binatang-binatang had-ya[391], dan binatang-binatang qalaa-id[392], dan jangan (pula) mengganggu orang-orang yang mengunjungi Baitullah sedang mereka mencari kurnia dan keredhaan dari Tuhannya[393] dan apabila kamu Telah menyelesaikan ibadah haji, Maka bolehlah berburu. dan janganlah sekali-kali kebencian(mu) kepada sesuatu kaum Karena mereka menghalang-halangi kamu dari Masjidilharam, mendorongmu berbuat aniaya (kepada mereka). dan tolongmenolonglah kamu dalam (mengerjakan) kebajikan dan takwa, dan jangan tolongmenolong dalam berbuat dosa dan pelanggaran. dan bertakwalah kamu kepada 
Allah, Sesungguhnya Allah amat berat siksa-Nya. [Q.S Al-Maidah [5]: 2] (Al-Qur'an dan Terjemahnya Departemen Agama RI, 1991).

Dalam lingkungan masyarakat anak akan memperlajari hal-hal yang baik, sebaliknya anak juga mempelajari hal-hal yang buruk. Tingkah laku sosial serta norma-norma lingkungan tempat anak bergaul tercermin pada kelakuan anak-anak. Di sinilah peran seluruh masyarakat menjadi sangat penting. Untuk itu, sudah jelas masyarakat harus berpartisipasi dalam mewujudkan karakter baik dalam diri individu yang nantinya akan menjadi tatanan hidup bagi seluruh warga negara (Abdullah Idi, 2011). Terdapat elemen-elemen penting yang menitikberatkan kepada masyarakat dalam pendidikan karakter. Di antara elemen-elemen tersebut sebagai berikut:

a. Menjadikan masyarakat sebagai penyeru kebaikan dan pelarang kemungkaran.

b. Menjadikan anak-anak di lingkungannya seperti anak sendiri.

c. Mempraktikanhukum-hukum syariahdalam mendisiplinkan masyarakat.

d. Bertanggung jawab mencerdaskan anak-anak dengan jam belajar masyarakat.

e. Menjaga fitrah anak agar tidak melakukan penyimpangan moral.

f. Menumbuhkan keutuhan masyarakat untuk saling bekerja sama dan saling memberi kasih sayang (Anas salahudin dan Irwanto Alkrienciehie, 2013).

Dari paparan di atas, dapat diketahui bahwa pendidikan karakter yang efektif dan bisa maksimal bila adanya intervensi dan peran serta masyarakat dalam memberikan pendidikan karakter. Peran serta masyarakat melalui pembiasaan dengan memberikan teladan dan contoh nilai-nilai moral di lingkungan sosial anak. Selain itu, masyarakat juga memiliki tanggung jawab dan andil dalam pendidikan, hal ini juga tertera dengan (Undang-undang Sistem Pendidikan Nasional No. 20 Tahun 2003).

Jun Sung Hong dan James Garbarino menyatakan bahwa karakter individu sangat dipengaruhi oleh berbagai aspek seperti keluarga, sekolah, teman sebaya, masyarakat dan budaya. Bahkan, semua level dalam teori ekologi lingkungan saling bersinergi dan saling memperkuat dalam memberikan pengaruh terhadap tingkah laku atau karakter indivudual. Hong juga menunjukkan contoh seperti kasus homophobic bullying yang terjadi di sekolah. Menurutnya, bukan hanya dipengaruhi oleh satu aspek saja, namun semua aspek dalam seperti keluarga, sekolah, teman sebaya, masyarakat dan budaya memberikan pengaruh terhadap terjadinya sikap homophobic. Untuk mencegah bahaya dan budaya homophobic bullying tersebut, harus dilakukan pembiasaan (practice) dan kebijakan (policy) dari sekolah yang harus melibatkan masing-masingaspek perkembangan anak agar dapat mencapai hasil yang maksimal (Jun Sung Hong and James Garbarino, 2012).

Senada dengan David W. Johnson and Roger T. Johnson, yang menitikberatkan pendidikan moral dan karakter yang inheren dengan aspek sosial. Nilai-nilai moral yang terkait aturan prilaku benar atau salah, erat hubungannya dengan interpersonal manusia. Keduanya berargumen bahwa sosialisasi pendidikan moral yang sukses dan konstruktif tergantung pada keberadaan komponen keluarga, sekolah dan masyarakat. Oleh karena itu, nilai-nilai moral harus diberikan oleh kelompok sosial seperti keluarga, sekolah dan masyarakat yang harus kooperatif antara satu dengan yang lainnya (David W. Johnson and Roger T. Johnson, 2014).

Pernyataan serupa juga dikemukakan oleh M. Halomoan yang mengemukakan bahwa keluarga, sekolah dan masyarakat (lingkungan sosial) sama-sama memiliki peran utama dalam menumbuhkan karakter positif anak (M. Halomoan, 2014). Keluarga dan masyarakat harus membiasakan anak untuk senantiasa 
mengaplikasikan nilai-nilai karakter dalam kehidupan sehari-hari. Untuk pengembangan nilai karakter di sekolah, semua agen atau stokeholder sekolah turut ikut serta dalam menenamkan nilai-nilai pada anak.

Mengenai ihwal ini, adanya penguatan dari beberapa tokoh seperti Abdul Majid, Jama>I 'Abdur Rahma>n, Moh. Solikodin Djaelani, Muchlas Samani dan 'Abdullah Nashih 'Ulwan yang juga mengatakan bahwa pendidikan karakter bukan hanya menjadi tanggung jawab lembaga pendidikan sekolah saja, tetapi keluarga dan masyarakat juga turut bertanggung jawab dalam memberikan pendidikan akhlak kepada anak Lihat (Abdul Majid dan Dian Andrayani, 2011). Dalam proses pembentukannya, sekolah harus mempunyai progam yang melibatkan keluarga (orang tua) dan masyarakat untuk mengajarkan dan menjadi teladan bagi anak. Di samping itu, keikutsertaan orang tua dan masyarakat dalam proses belajar mengajar, dapat menumbuhkan gairah anak dalam belajar. Hasilnya akan tampak pada pengembangan program kerja sama dalam hubungan antara sekolah, orang tua dan masyarakat (Abdul Majid dan Dian Andrayani, 2011).

Perihal ini pun telah dinyatakan oleh Darmiyati, bahwa menurutnya ketiga lembaga pendidikan seperti: keluarga, sekolah dan masyarakat harus terintegrasi satu sama lain dalam pendidikan karkater. Darmiyati menuturkan jika ketiga lembaga tersebut interdependensi dalam program atau pendekatan yang diistilahkan olehnya sebagai pendekatan komprehensif. Pendekatan ini menurutnya efektif, karena pendekatan ini, tak sebatas pada integrasi ke dalam berbagai bidang studi. Metode dan strategi yang digunakan bervariasi yang sedapat mungkin mencakup inkulkasi/penanaman (lawan indoktrinasi), keteladanan, fasilitasi nilai, dan pengembangan soft skills (antara lain berpikir kritis, kreatif, berkomunikasi efektif, dan dapat mengatasi masalah) (Darmiyati dkk, 2010).

Selain itu, pada proses pemberian teladan, bahwa semua lini sekolah (pimpinan sekolah, guru, siswa, pegawai administrasi, bahkan penjaga sekolah serta pengelola warung sekolah) dan orang tua murid serta pemuka masyarakat perlu bekerja secara kolaboratif dalam melaksanakan program pendidikan karakter. Tempat pelaksanaan pendidikan karakter baik di dalam kelas maupun di luar kelas dalam berbagai kegiatan, termasuk kegiatan di rumah dan di dalam lingkungan masyarakat, dan hal ini juga dapat diberikan jika adanya partisipasi orang tua (Darmiyati dkk, 2010).

Kemudian, Mundiharno dan Abdullah Ubaid memberikan alasan secara rinci terkait perlunya partisipasi masyarakat dalam memberikan pendidikan. Beberapa argumen yang mereka kemukakan sebagai berikut:

1. Masyarakat adalah fokus utama dan tujuan akhir dari kebijakan dan program pemerintah. Karena itu, masyarakat harus tau dan terlibat dalam kebijakan pemerintah. Jika tidak, pemerintah bisa semena-mena melaksanakan kebijakan dengan seenaknya, disebabkan masyarakatnya hanya diam saja.

2. Partisipasi akan menciptakan arus informasi yang terbuka. Misalnya tentang sikap, aspirasi, kondisi lokal, dan kebutuhan masyarakat. Tanpa adanya partisipasi masyarakat, tentu semua informasi itu niscaya tidak akan terungkap. Informasi dari masyarakat akan sangat bermanfaat untuk mencapai keberhasilan program pemerintah.

3. Apa yang dihadapi dan dibutuhkan oleh masyarakat adalah masyarakat sendiri yang tahu. Dengan adanya partisipasi, pelayanan pemerintah dapat dicapai lebih cepat dan tepat, sebab masyarakat mengetahui dimulai dari mana, dan dari apa yang mereka meliki sendidri.

4. Partisipasi merupakan cara yang efektif dalam membangun kemampuan masyarakat, untuk mengelola program, guna memenuhi kebutuhan lokal. 
Karena itulah, partisipasi dipandang sebagai cerminan hak-hak individu untuk dilibatkan dalam kepentingan yang bertujuan untuk kebaikan mereka sendiri (Mundiharno dan Abdullah Ubaid, 2017).

Selain keempat alasan di atas, menurut keduanya, bahwa terdapat landasan Yuridis yang menekankan perlunya partisipasi masyarakat. Hal ini dapat dilihat dalam Peraturan Pemerintah No. 17 Tahun 2010. Hal ini menunjukkan bahwa partisipasi masyarakat dalam pendidikan berarti kontribusi dan keikutsertaan masyarakat dalam menunjang upaya peningkatan mutu pendidikan, peran serta masyarakat ini berfungsi untuk memperbaiki akses, mutu, daya saing, relevansi, tata kelola, dan akuntabilitas pengelolaan dan penyelenggaraan pendidikan (Mundiharno dan Abdullah Ubaid, 2017).

Jelasnya, dalam hal pendidikan, masyarakat juga harus ikut andil dalam mewujudkan pendidikan berkualitas di sekolah. Karena telah diketahui secara masif, bahwa pendidikan karakter bukan hanya tanggung jawab pemerintah, sekolah, juga guru, tetapi juga perlu peran serta keluarga dan masyarakat. Tanpa adanya sinegi ketiga lembaga, pendidikan akan berujung pada kegagalan.

Sinergi ketiga lembaga ini, harus terjalin dengan intens. Sekolah dengan keluarga dan masyarakat, hingga benar-benar menjadi mitra yang baik. Sekolah harus selalu menjalin interaksi dengan keluarga siswa, misalnya melalui surat, $e$ mail, rapat orang tua (PTO) dan sebagainya (Muchlas Samani, 2013). Selain itu, melibatkan keluarga dan masyarakat untuk berpartisipasi dalam pembentukan karakter, yaitu dengan membiasakan dan mengajarkan ketuhanan dan moral dalam diri anak yang dilakukan oleh orang tua di rumah dan di masyarakat (Jamal 'Abdal-Rahman, 2013).

Perihal keterkaitan dan melibatkan masyarakat dalam pendiidkan karakter, masyarakat dapat berperan serta membantu orang tua dengan lembaga sekolah melibatkan dan menjadikan masyarakat sebagai anggota workshop dan seminar. Dalam kegiatan seminar orang tua dan masyarakat akan mempelajari pengetahuan dasar yang sangat bagus untuk mempelajari berbagai teori psikologi anak dan keluarga. Memahami konsep menangani anak di rumah dan di sekolah, serta lebih mudah mengerti dan memahami jalan pikiran anak, pasangan dan orang lain (Sri Haryati, 2017). Padangan serupa juga diungkapkan oleh S, Wisni Septiarti yang mencanangkan jika inidividu pada sema hidupnya sebagaian besar dipengaruhi oleh tiga lingkungan pendidikan yang utama yakni keluarga, sekolah dan masyarakat. Dan ketiga lingkungan pendidikan ini dalam pendangannya, memiliki peranan yang sangat utama. Bahkan menurut Sri pengaruh ketiga institusi pendidikan ini sudah tidak ada perbedaan besar dalam hal memberikan pengaruh keapada anak. Lebih lanjut menurut Sri dalam membangun karakter keterlibatan ketiga institusi ini harus sudah terlihat dari sejak anak pada masa dini (S.Wisni Septiarti, 2019).

Pada tahap pelaksanaan pendidikan karakter, ketiga institusi ini saling bersinergi dan memiliki tanggung jawab bersama. Pendidikan karakter dimulai dari keluarga. Sementara itu dalam perkembangan usia anak, sekolah dan masyarakat juga sudah terlibat dalam mengembangkan kepribadian dan karakter anak. Pendidikan karakter pada satu sisi memiliki tujuan untuk mengurangi perilakuperilaku destruktif pada anak remaja dan orang dewasa bahkan di kalangan pelajar dan mahasiswa. Perilaku destruktif yang makin bergema di Indonesia, pada semua lini kehidupan. Barangkali terjadi oleh karena begitu minimnya keteladanan oleh orang tua, pendidik atau orang dewasa lain baik secara langsung dan tidak langsung. Penanaman nilai keteladanan tentang nilai-nilai kejujuran, kebajikan yang berakar pada agama, budaya atau kesepakatan umum seperti budi pekerti 
dan keteladanan sangat penting dilakukan secara terus menerus sejak dini (S.Wisni Septiarti, 2019).

Sebagai penguatan pendidikan karakter di sekolah Kemendikbud dan Menristekdikti telah memberikan blue print atau amanat baku untuk pelaksanaan dan penguatan pendidikan karakter di sekolah. Penguatan pendidikan karakter yang diamanatkan yaitu interdependensi Tri Pusat Pendidikan atau Educational Institutions (Peraturan Presiden No. 87 Tahun 2017).

Menurut Menristekdikti Penguatan Pendidikan karakter atau yang dikenal dengan PPK ini sebagai pintu masuk untuk melakukan pembenahan secara menyeluruh terhadap pendidikan di Indonesia. selain itu, menurut Mendikbud, PPK bertujuan untuk memperkuatn kurikulum 2013 dan bukan merubah struktut kurikulum.

Dalam pengimplementasiannya, PPK dilakukan dengan modifikasi pada kegiatan intrakurikuler agar lebih memiliki muatan pendidikan karakter. Kemudian ditambahkan kegiatan dalam kokurikuler dan ekstrakurikuler. Integrasi dari ketiga aspek ini diharapkan dapat menumbuhkan budi pekerti dan menguatkan karakter positif anak didik (Ristekdikti, akses 2019). Menurut Ristekdikti pada prinsipnya penerapan PPK juga pada manajemen berbasis sekolah, lalu lebih banyak melibatkan siswa pada aktivitas daripada metode-metode konvensional seperti ceramah tanya jawab dan lain-lain. Kemudian kurikulum berbasis luas atau broad based curriculum yang mengoptimalkan pemanfaatan sumber-sumber belajar (Ristekdikti, akses 2019).

PPK mendorong sinergi tiga pusat pendidikan, yaitu sekolah, keluarga (orang tua), dan komunitas (masyarakat) agar dapat membentuk suatu ekosistem pendidikan. Menurut Mendikbud, selama ini ketiganya seakan berjalan sendirisendiri, padahal jika bersinergi dapat menghasilkan sesuatu yang luar biasa. Diharapkan manajemen berbasis sekolah semakin menguat, di mana sekolah berperan menjadi sentral, dan lingkungan sekitar dapat dioptimalkan untuk menjadi sumber-sumber belajar (Ristekdikti, akses 2019). Berikut gambaran pola pendidikan karakter yang terintergrasi:

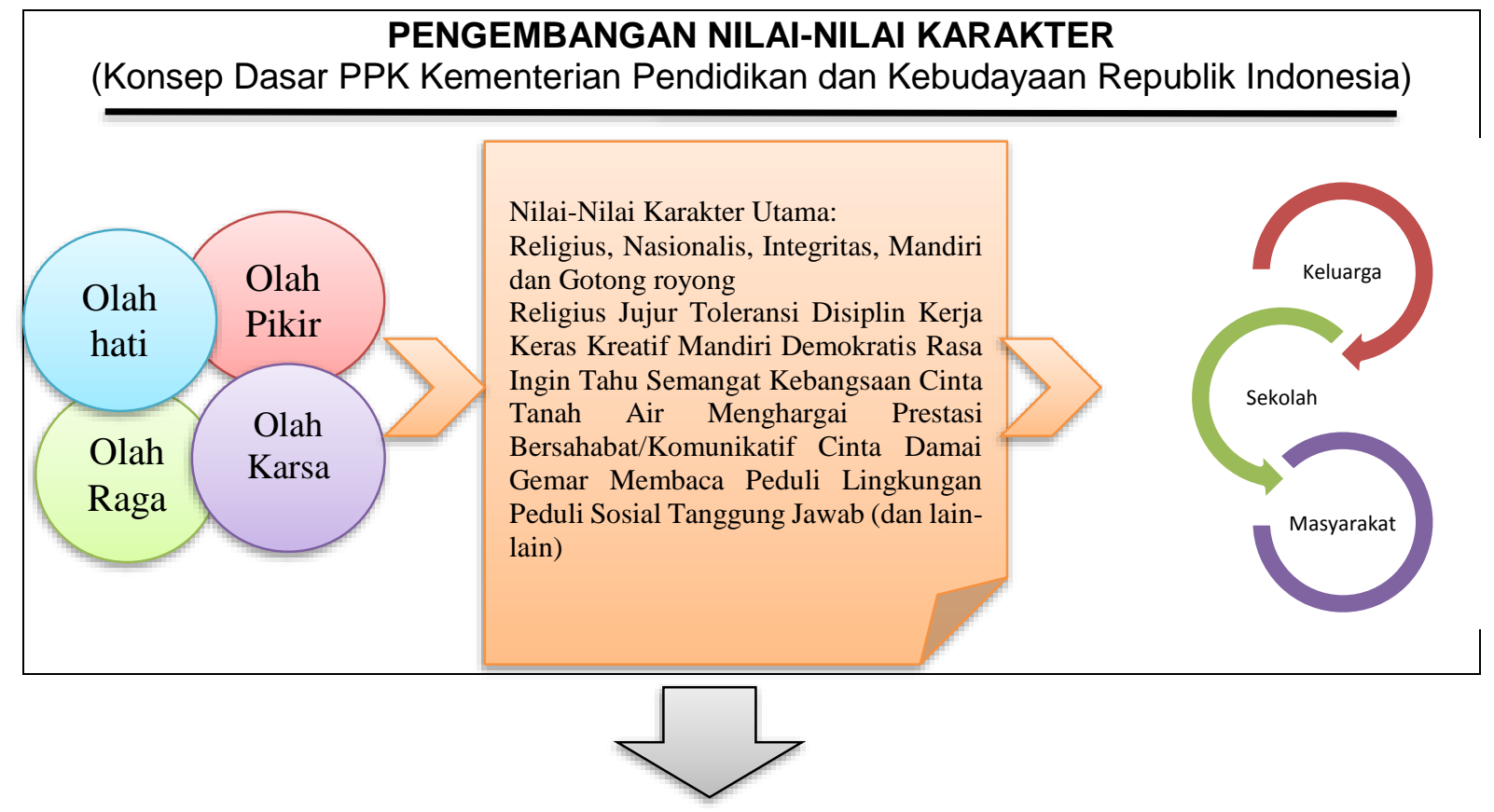




\section{Skema Grand Design Educational Institutions dalam Pendidikan Karakter:}

PENDIDIKAN KARAKTER

Integrasi Keluarga, Sekolah dan Masyarakat

Keluarga: Pembiasaan hal-hal positif oleh orang tua, dan saudara

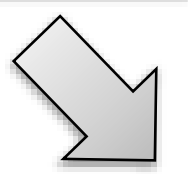

Sekolah:

Kegiatan Pembiasaan* Sekolah Kegiatan Intra Kurikuler* Ekstra Kurikuler*

Dan Ko-Kurikuler

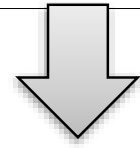

Masyarakat: Terlibat dalam program pemerintah dan sekolah

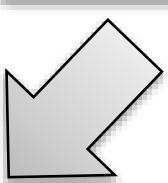

Habituasi/Pembiasaan (Skema mengadopsi dari Simluasi Model PPK Kementerian Pendidikandan Kebudayaan Republik Indonesia)

Keterangan:

*Kegiatan Pembiasaan : Memulai hari dengan Upacara Bendera(Senin), Apel,menyanyikanlagulndonesia Raya, LaguNasional, danberdoa bersama. Membaca buku-buku non-pelajaran tentangPBP, cerita rakyat, 15 menit sebelum memulai pembelajaran.

*Kegiatan Intra Kurikuler: Kegiatan belajar mengajar di dalam kelas sebelum menutup hari Siswa melakukan refleksi, menyanyikan lagu daerah dan berdoa bersama.

*Kegiatan Ko-Kurikuler dan Ekstrakurikuler: Sesuai minat dan bakat siswa yang dilakukan di bawah bimbingan guru/pelatih/melibatkan orang tua \& masyarakat: KegiatanKeagamaan, Pramuka, PMR, Paskibra, Kesenian,Bahasa \& Sastra, $\mathrm{KIR}$, Jurnalistik, Olahraga, dsb.

Dari penjelasan di atas, dapat diambil titik terang bahwa pendidikan karakter tidak hanya berpusat pada satu lembaga atau satu lingkup saja. Jika dilihat peranan dari masing- masing lembaga pendidikan seperti keluarga, sekolah dan masyarakat serta negara perlu menyadari bahwa membangun pendidikan karakter dan menanamkan kebiasaan yang baik terhadap anak merupakan kebutuhan bersama.

\section{Simpulan}

Adanya perbedaan pendapat atau pandangan yang dapat diklasifikasikan dalam beberapa pandangan dan teori seperti sebagian pendapat yang mengatakan keluarga atau orang tualah yang paling utama atau memiliki tanggung jawab penuh dalam memberikan pendidikan karakter. Untuk itu, perlunya Grand Design of terhadap Educational Institutions (Institusi Pendidikan) atau rumusan pendidikan karakter yang kompehensif terkait permasalahan tersebut.

Dari hasil bahasan dan anlisa di atas, dapat diambil kesimpulan yang nyata, bahwa penangung jawab pendidikan karakter anak tidak bisa dibebankan pada satu aspek seperti keluarga, sekolah atau masyarakat saja pada Educational Institutions. Namun, semua aspek atau institusi pada Educational Institutions turut berperan, bahkan semuanya memiliki tanggung jawab penuh menjadi pendidik 
karakter anak. Dengan menganalisa pendapat-pendapat konkret tentang tanggung jawab penuh oleh Educational Institutions dari berbagai tokoh seperti: Thomas Lickona, Jun Sung Hong dan James Garbarino, David W. Johnson and Roger T. Johnson dan lain-lain. selain itu, tokoh-tokoh muslim seperti Abdul Majid, Jama>l 'Abdur Rahma>n, Moh. Solikodin Djaelani, Muchlas Samani dan 'Abdullah Nashih 'Ulwan yang secara jelas juga menerangkan pendidikan karakter bukan hanya menjadi tanggung jawab lembaga pendidikan sekolah saja, tetapi keluarga dan masyarakat juga turut bertanggung jawab dalam memberikan pendidikan karakter/akhlak kepada anak.

Hal ini diperkuat lagi dari aspek Yuridis seperti yang telah tertera pada Undang-undang Sisdiknas No. 20 Tahun 20003, Permendikbud No21, 22, 23 dan 24 terkait atauran dasar (besic rules) dalam Pengembangan Kurikulum 2013 dan terakhir pada Peraturan Presiden no 87 tahun 2017 yang kemudian dikuatkan lagi oleh Permendkbud No. 20 tahun 2018 tentang Penguatan Pendidikan Karakter pada satuan pendidikan formal. Dengan adanya blue print atau acuan dasar dari berbagai tokoh dan standar bahu dari prodak undang-undang RI. Maka, hasil dekripsi inilah yang dapat dijadikan sebagai Grand Design of Educational Institutions dalam dunia pendidikan karakter.

\section{DAFTAR PUSTAKA}

[1] Abdal-Rah\}ma>n, Jama>l. At\}fa>lal-Muslimisn Kaifa Raba>hum NabiyalAmi $>$ n. Makkah al-Mukaramah: Da>r al-T\{aybah al-Khad\}r, 2000.

[2] Al-Di>n, Na>diyah Jama>l Falsafah al-Tarbiyyah 'inda Ikhwa>n al-Syafa>. Kairo, al-Markaz al-A'rabi li al-Shiha $>$ fah, 1983.

[3] Al-Nah\}lawi>, Abd al Rahma>n. Us\}u>l al-Tarbiyah al-Isla>miyah wa Asa>libiha fi al-Bayt wa al-Madrasah waal-Mujtama'. t.t

[4] Al-Nahlawi>, Abd al Rahma>n Usul al-Tarbiyah al-Isla>miyah wa Asa>libiha fi al-Bayt wa al-Madrasah waal-Mujtama. Beirut: Da>r Al-Fikr Al-Mu'asir, 1983.

[5] Al-Naqi>b, Abd Abd al-Rahma>n. Falsafat al-Tarbiyah inda Ibn Sina>. Kairo: Da>r al-Tsaqa $>$ fah, 1984.

[6] Al-Qur'an dan Terjemahnya. Departemen Agama RI, 1991.

[7] Bertens, K. Etika. Jakarta: PT Gramedia Pustaka Utama, 2007.

[8] Daradjat, Zakiah. Pendidikan Islam dalam Keluarga. Jakarta: Bumi Aksara, 2008.

[9] Kesuma, Dharma dkk. Pendidikan Karakter Kajian Teori dan Praktik di Sekolah. Bandung: PT Remaja Rosdakarya, 2012.

[10] Lickona, Thomas Pendidikan Karakter. Bantul: Kreasi Wacana, 2012. Judul asli Character Metters. Touchstone: New York, 2004.

[11] Lickona, Thomas. Education for Character Education, How Our School Can Teach Respect and Responsibility. New York: Bantam, 1991.

[12] Majid, Abdul dan Dian Andrayani. Pendidikan Karakter Perspektif Islam. Jakarta : PT Rosdakarya, 2011.

[13] Mundiharno dan Abdullah Ubaid. Toolkit: Pengauatan Partisipasi Masyarakat Melalui Komite Sekolah. Jakarta: Lapesdam, 2017.

[14] Nucci Larry dalam Merle J. Schwartz, Effective Character Education: A. Guidebook for Future Educator. New York: Mc Graw Hill, 2007.

[15] Samani, Muchlas. Konsep dan Model Pendidikan Karakter. Bandung: PT Remaja Rosdakarya Offset, 2013. 
[16] Schwartz, Merle J. Effective Character Education: A. Guidebook for Future Educator. New York: Mc Graw Hill, 2007.

[17] Shihab, M. Quraish Tafsir Al-Misbah. Jakarta: Lentera Hati, 2003.

[18] Ulwan, Abdullah Nashih. 'Tarbiyat al-Awla $>d$ fi> al-Isla $>m$. Kairo: Dar al-Salam li> al-T\{iba' wa al- Nashr wa al- Tawzi>', 1981.

[19] Davidson Matthew and Thomas Lickona. Smart and Good School: A New Paradigm for Hight School Character Education, dalam Larry P. Nucci.

[20] Association for Supervision and Curriculum Development, "Moral Education in The Life of the School." ASCD Penel on Moral Education (1998), 4-5, http://www.ascd.org/ASCD/pdf/journals/ed_lead/el_198805_p4.pdf (diakses pada tanggal 34 April 2014).

[21] Augustin, Meita Purnamasari. Tesis: "Pengaruh Terpaan Media Internet Terhadap Karakter Siswa :Studi terhadap Siswa SMA Negeri di Kota Cimahi (2010). Lihat http://repository.upi.edu/9845/.

[22] Bush George W. "Pendidikan karakter menjadi fokus utama dari agenda reformasi pendidikannya."

Lihat http://education.stateuniversity.com/pages/2246/Moral-Education.html.

[23] Clarken, Rodney H. "Moral Intelligence in the Schools." Paper presented at the Annual Meeting of the Michigan Academy of Sciences, Arts and Letters Wayne State University (2009) http://files.eric.ed.gov/fulltext/ED508485.pdf.

[24] Dahlan Djawad dan Juntika Nurihsan. "Personality Depelopment: Pengaruh Keluarga, Pendidikan dan Masyarakat Terhadap Kepribadian." http://file.upi.edu/Direktori/Personality_Development.pdf (diakses pada tanggal 24 Juni 2014).

[25] Djaelani, Moh. Solikodin. "Peran Pendidikan Agama Islam dalam Keluarga dan Masyarakat." Jurnal IImiah 1, no. 2 (2013).

[26] Darmiyati dkk, "Pengembangan model pendidikan karakter terintegrasi dalam pembelajaran bidang studi di Sekolah Dasar," Jurnal Cakrawala, Mei (2010), Edisi Khusus Dies Natalis UNY lihat file:///E:/Jurnal\%20Mentah/Model\%20Pendidikan\%20Karakter/Permasalahan /Macam2\%20Pendektan\%20Pendidikan\%20Karakter.pdf (diakses pada tanggal 20 Februari 2019).

[27] Ekumoto, Taku. "Moral Issu" (2007). www.hi.hone.jp/taku77/refer/kilpat.htm

[28] Fajarini, Ulfah. "Peranan Kearifan Lokal dalam Pendidikan Karakter," JurnalFakultas Tarbiyah Universitas Islam Negeri (UIN) Syarif Hidayatullah Jakarta, www.journal.uinjkt.ac.id/index.php/SOSIO-FITK

[29] Fauzee, M. S. Omar. "The Strategies for Character Building through Sport Participation." International Journal of Academic Research in Business and Social Sciences 2, no. 3 ( 2012), 2222-6990.

[30] Halomoan, M."Kajian Terhadap Pengembangan Nilai-Nilai Pendidikan Karakter Bangsa di Satuan Pendidikan."http://sumut.kemenag.go.id

[31] Halstead J. Mark and Monica J. Taylor. "Learning and Teaching about Values: A Review of Recent Research." Cambridge Journal of Education 30. no. 2 ( 2010), 169-202

[32] Haryati, Sri. "Pendidikan Karakter dalam Kurikulum 2013," lihat http://lib.untidar.ac.id/wp-content/uploads/2017/01/Pendidikan-Karakterdalam-kurikulum.pdf.

[33] Haryati, Sri. "Pendidikan Karakter dalam Kurikulum 2013." lihat http://lib.untidar.ac.id/wp-content/uploads/2017/01/Pendidikan-Karakterdalam-kurikulum.pdf 
[34] Hong, Jun Sung and James Garbarino "Risk and Protective Factors for Homophobic Bulliying in Schools: An Application of the Social Ecological Framework." Educational Psychology Review 24, no. 2 (2012), 271-285, www.link.springer.com.

[35] Idi, Abdullah Sosiologi Pendidikan, Individu Masyarakat dan Pendidikan. Jakarta: Rajawali Pers, 2011.

[36] Izzaty, Rita Eka. "Pencerahan dan Kemandirian Peserta Didik: Sudut Pandang Psikologi Perkembangan," Jurusan Psikologi Pendidikan dan Bimbingan, Fakultas Pendidikan Universitas Negeri Yogyakarta (2013), http://staff.uny.ac.id/sites/default/files/pdf.

[37] Jito Subianto, "Peran Keluarga, Sekolah, Dan Masyarakat Dalam Pembentukan Karakter Berkualitas", lihat https://www.researchgate.net/publication/329520580.

[38] Johnson David W. and Roger T. Johnson. "Social Interdependence, Moral Character and Moral Education."dalam Larry P. Nucci, Handbook of Moral and Character Education. http//www.books.google.com/books?isbn=1136293124.

[39] Kaimuddin. "Implementasi Pendidikan Karakter dalam Kuikulum 2013." Jurnal Dinamika IImu, 14. No. 1, (2014) lihathttps://journal.iainsamarinda.ac.id/index.php.

[40] Nasiruddin. "Peran Keluarga, Sekolah, dan Masyarakat dalam Pendidikan Karakter Generasi Muda Bangsa." Prosiding Seminar Nasional Tahunan Fakultas IImu Sosial Universitas Negeri Medan Tahun 2017 Vol. 1 No. 12017 , Hal. 339-343. Lihat http://semnastafis.unimed.ac.id/wpcontent/uploads/2017/11/25.-NASIRUDIN.pdf

[41] Oladipo, S. E. "Moral Education of the Child: Whose Responsibility?." Journal of Social Science 20, no. 2 (2009),149-156, http://www.krepublishers.com/02Journals/JSS/Oladipo-S-E-Tt.pdf

[42] Peraturan Presiden No.87 Tahun 2017 tentang Penguatan Pendidikan Karakter, lihat https://setkab.go.id/wpcontent/uploads/2017/09/Perpres_Nomor_87_Tahun_2017.pdf Lihat juga Permendikbud No.20 Tahun 2018 tentang Penguatan Pendidikan Karakter pada Satuan Pendidikan Lormal. https://jdih.kemdikbud.go.id/arsip/Permendikbud_Tahun2018_Nomor20.pdf.

[43] Permana, Muhammad Riyan Adi. "Pengaruh Penggunaan Internet, Kontrol Sosial, dan Kontrol Diri Terhadap Karakter Siswa Kelas XII Program Keahlian Teknik Ketenagalistrikan SMKN 3 Yogyakarta." lihat http://eprints.uny.ac.id/19904/1/Muhammad\%20Rian\%20Adi\%20Permana\%2 009501244038.pdf.

[44] Permendikbud No. 21 Tahun 2016 tentang Standar Kompetensi Lulusan Dasar dan Menengah. Lihat http://bsnp-indonesia.org/wpcontent/uploads/2009/06/Permendikbud_Tahun2016_Nomor021_Lampiran.pd $\mathrm{f}$.

[45] Peterson Buser C.H. and N.G. Westburg, "Effects of Familial Attachment, Social Support, Involvement, And Self-Esteem on Youth Substance Use And Sexual Risk," The Family Journal 18,no.4 (2010): 369376,http://tfj.sagepub.com/content/18/4/369. 
[46] Peterson. Christina Hamme an others. "Effects of Familial Attachment, Social Support, Involvement, And Self-Esteem on Youth Substance Use And Sexual Risk," The Family Journal 18,no. 4 (2010), 369-376, http://tfj.sagepub.com/content/18/4/369.

[47] Rawana, Justin R. E. and Raymond. "The Application of a Strength-Based Approach of Students' Behaviours to the Development of a Character Education Curriculum forElementary and Secondary School." The Journal of Educational Though 45 no. 2 (2011). 127, http//proQuest.com

[48] Ristekdikti. "Penguatan Pendidikan Karakter, Pintu Masuk Pembenahan Pendidikan Nasional." lihat https://ristekdikti.go.id/siaran-pers/siaran-perskemendikbud-penguatan-pendidikan-karakter-pintu-masuk-pembenahanpendidikan-nasional/\#v8PfXICOjCv3Weol.99.

[49] S. E. Oladipo. "Moral Education of the Child: Whose Responsibility?", http://www.krepublishers.com/02-Journals/JSS/Oladipo-S-E-Tt.pdf.

[50] Salahudin, Anas dan Irwanto Alkrienciehie, Pendidikan Karakter Berbasis Agama dan Budaya Bangsa

[51] Septiarti, S.Wisni. "Peran Pendidik dan Sekolah dalam Pendidikan Karakter Anak: Paper disampaikan dalam acara seminar parenting "Pendidikan Karakter Berbasis Keluarga dan Sekolah," lihat http://staffnew.uny.ac.id/upload/131656352/pengabdian/peran-pendidik-dansekolah-dalam-pend-karakter.pdf.

[52] Smith Emilie Phillips and others. "Family, School, and Community Factors and Relationships to Racial-Ethnic Attitudes and Academic Achievement." American Journal of Community Psychology 32, no.4 (2003)http://www.researchgate.net

[53]Smith, Emilie Phillips and others. "Family, School, and Comminity Factors and Relationships to Racial-Ethnic Attitudes and Academic Achievement," American Journal of Community Psychology 32, no.4 (2003), http://www.researchgate.net (diakses pada tanggal 23 Januari 2014).

[54] Sudewo, Erie. Best Practice Character Building. Jakarta: Republik Penerbit, 2011.

[55] Sweet David H. Elkind dan Freddy. "How to Do Character Education." Today's School, (2004), http://www.goodcharacter.com/article_4

[56] Undang-undang Republik Indonesia No. 20 Tahun 2003 Tantang Sistem Pendidikan Nasional.www.kemenag.go.id/file/dokumen/UU2003.pdf

[57] Williams, Mary M. "Models of Character Education: Perspectives and Developmental Issues," The Journal of Humanistic Counseling, Education and Development 39, no. 1(2000), 32-40, http://connection.ebscohost.com/c/articles/3517623/modelscharactereducation-perspectives-developmental-issues. 